らのいの後認にてさ慢認の

たと性。分者識 イ、しに識把認

めこ格認析 の的 ゙自く自の捉識

てろ的識結問側オ芑こ芑様には

フで把の果題面口点のの態ほつ

個、握構をににギ検よ姿もかね

人アが造通深関はとうをまなに

人メ必要要主内なかたら何

のリ要解て関る体面変え市

重力な明、連分の的化てそいか

み社の立前析方発を行の。の

を会でる者むに法展要く変し対

理学あたのつつ論の請で化た象

解にるめ問もい的必さあをがを

しお。に題のて再要れろ追っ有

そけはにでで規をてうってす

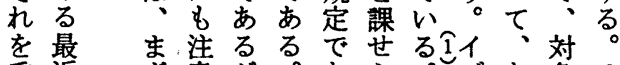

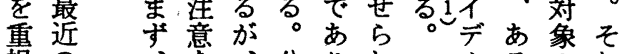

視の、堭、、分りれそオるなれ

寸特諗はそ析、てれ口い内は

る色識らの体第いはギは面対

観的者わ前系兰る年 1 鋭的象

点傾 な提論に。次分角変の

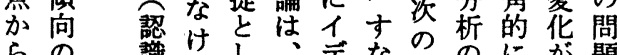

らの識けしし、゙なののに品題

二—溨れて直才わ二現あ生性

連つるばお接口ち点段る元あ

のは主なよ的ギ、に階いたる

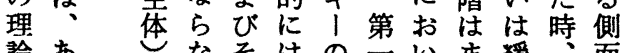

論あ ‘なそはの一いま楥 ‘面

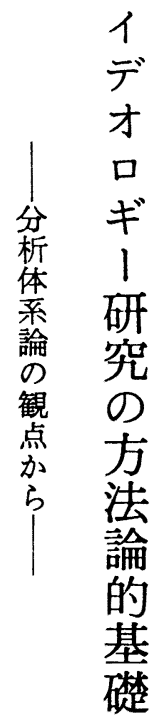

考一 口的性基 2 的自固腐本為 $え$ 不的

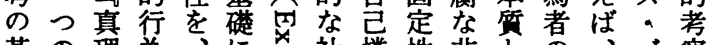

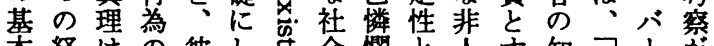

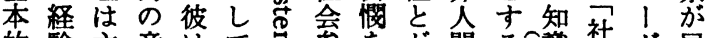
的験主意はて䓌参老夜間る镜社力゙展

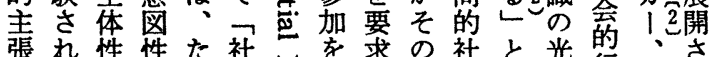

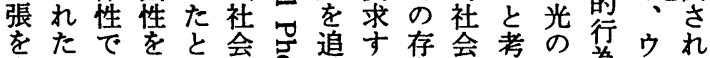
完真あ社え的怘求る在会考宁為ウれて 全理る会は実字すこ的らるにはルい にでる学次存吊ると基のテ、過 フ4る

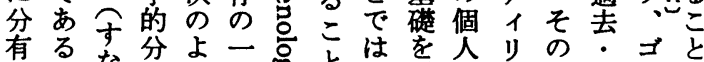

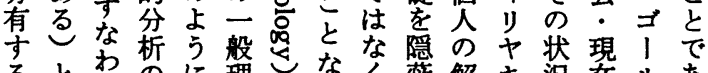
るとわ场理な蔽解キ洗在ルあ

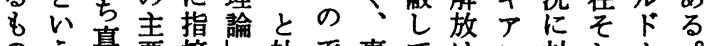
のう真要摘社で真て法対しす。

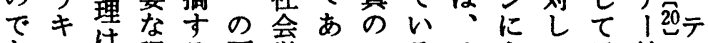

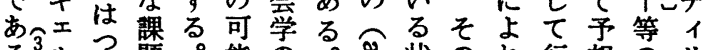
る゙ルす題。能の产桨のれ行想のリ

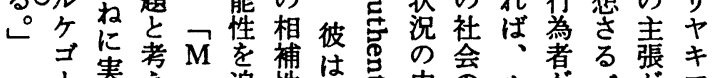

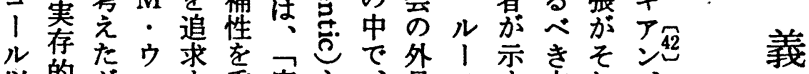
以的夯守重実主、筧テ尔末れ 来自、1る視存体乃的1主来でべ の我こバ。し的的ナなン体にあン 実にの门そ、現か门客化的関るテ 存とこはのそ象つキ観し志寸。1 的っと社相れ学連 1 性た向るたッ 思ては会補をし带やと陳を行とク 
るの関てがまるらさ義生模見ひ

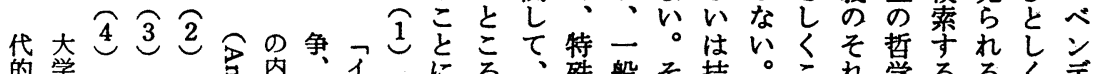

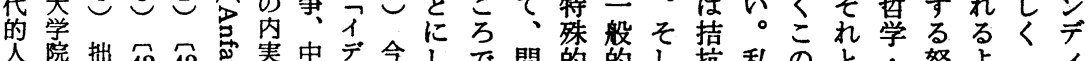

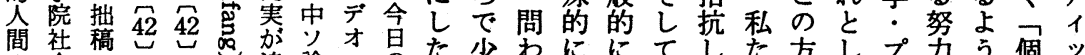

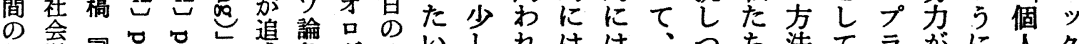
認学、? 識研

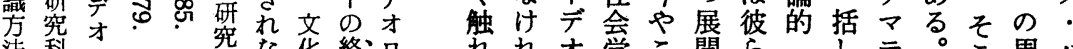

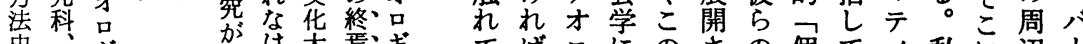

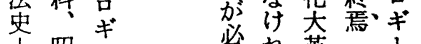

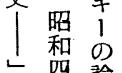
要䈏革命状

お四論

よ年構

ひ度 造

第 葆

章論

文析

社 炎 体

会第系

人章序

間章説

$\mid$ 鼻

近

的間東

間|近学

あ゙な景洗

な本の少

と現そな

心桨でく

うのでを

意でな昌

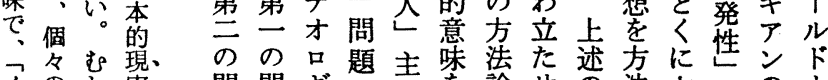

てばロにのさの個てィ私に辺 |

いなギおよれ考人論ズははをガ

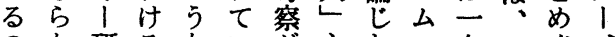

のな研るない主た。九個ぐ、

でず્い究社方るパ義こ実世的るウ

こでお会論とソ観が焦简間テル

こあけと的の二点あ義後の们、

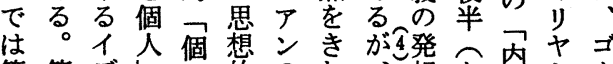

第第デん金的のわ、想々発キ1

イのし実問問ギと義㖈論せの法七てのナ

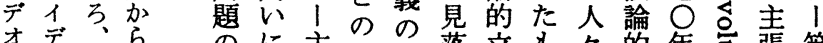

牙占見展つ体対発落妾も各的年吉張等

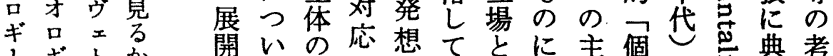

の1ナぎをて規にのは平ほ張人以型察

端、主

初体 戦

たは定お意な行かはし来

ど他にい味るあなま主のをに

で対つし求りオる。とろト、点る学る

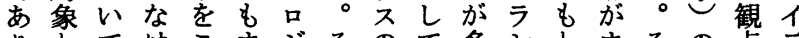

りとてけこまジそのて多ジをその点テ

、しのれと导、れ哲く仙よすきこ観は才

し、学ばと彼とに学さ、のり明で点素口

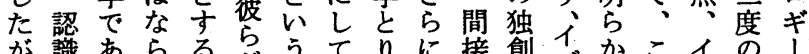

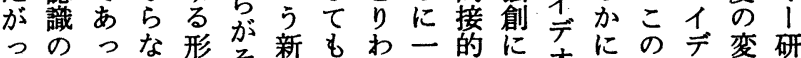

て唯たい而そ多、け七によ才さよ才花究

そ一心。上䒠称力释世はる机う口をの

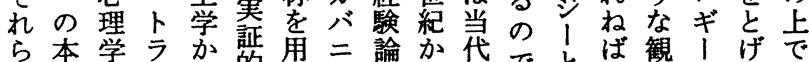

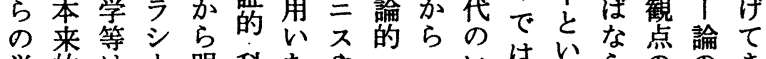

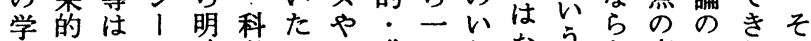

は対私に確学のト唯入わなう概な変そたら

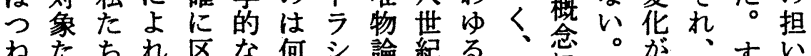

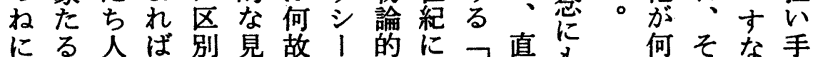

現諸間、品地でがなかて接もりをしわと

実事の形よをあそ㤵けテ的り

遊実認而う本乃の蒙てオに文

離の識上と質う思のの品は

の領能学し存か考主フは兮た

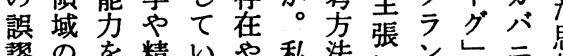

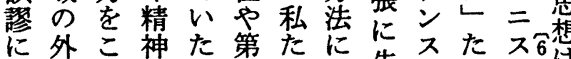

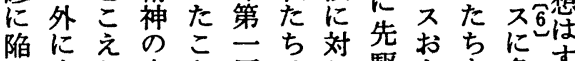

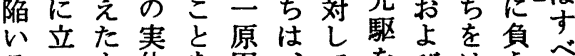

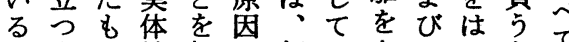

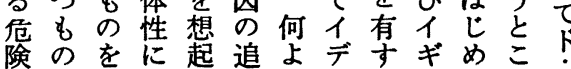

を党 ち

の知 、宁

が識イの

た 社 デ 人

つ会オ間

心学口主

るの ジ 主

加観

と点っに

いで観 対

うあ念倠

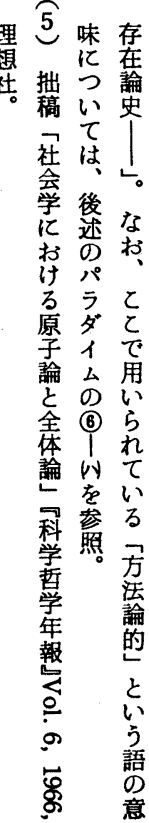


たおい本う的し人し言に以、形底生し全を的学を かも。有ちな得間な守を来し而用理てジ対イ具をと免 ぎ思し観にもるのけれとのた上的等第 I 象 ゙゙体事しれ り惟か念ものよ意ればう本が学にの焉でとオ的実てな 、としの見へう識ば、い有っの明相は、し学はににのい いい、主らとにのな私て観て態ら互比上、法は立イの まうそ張れ移な内らた形念、度か関較記そ、、朤テで た赛のはる行っになち成ごでに係イのこでイしオあ

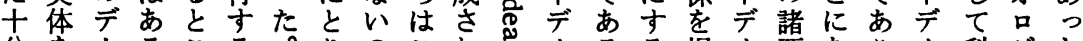
分をカるこる。りのこれるオるる选才要あり、才科ジた

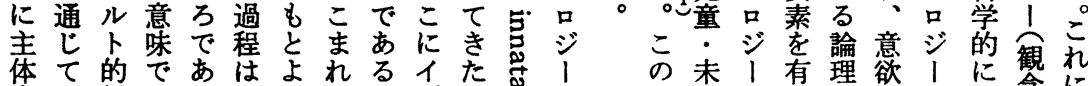

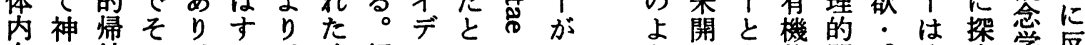
在の結の、で、時超オいに形引人占体関感次求学反 的超は移ルにイ、越口う依而 で越、行ネ遠デイ的ジこ拠上 あ的自をサく、テイ、と学 る存我完ンギがオデとがる气 と在に了スリ超口、イ、を はと内さ以シ越ジがデこのの いの在せ後厂的 |そ|こで主 い結化たと末なののとであた 難びさもり 期も見超ののるる かつれのわのの地越関眼ひ内 つきたにけスかは性俰目と容 たをイほデトら初ををでのは 保デかカア意め塤明あ対デ つ1なル哲識て失らる立力 てがらト学内成しか。意ル いななのの在立てに換識卜

に・ば的係賞の娄はし 異れなを员るる精て イ常る原追判つ新神彼 デ者を因求断のし現ら オ・のにす・部い象に 口動で結る記閏見とよ ジ物、び。憶か地外っ 1等精つ第とらに界て のに神け三そ成立と主 著つとてはれるつの張 しい身研生ら。連さ いて体究理の第の関れ 特実、文的運一でをた 色験道るイ動はああ新

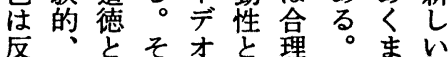

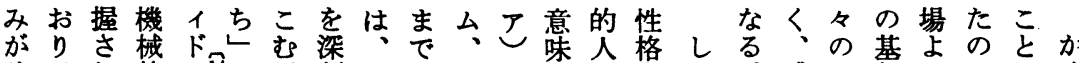

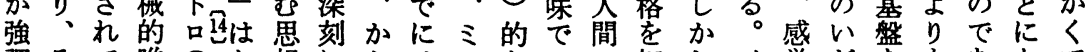

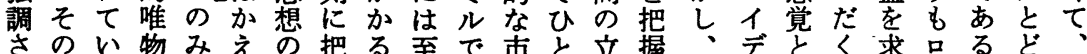

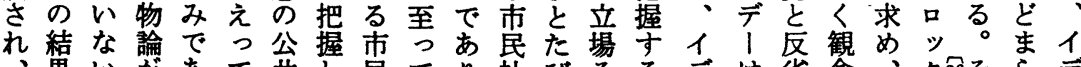

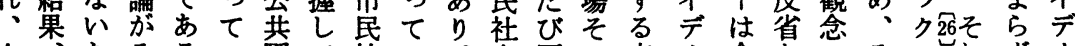

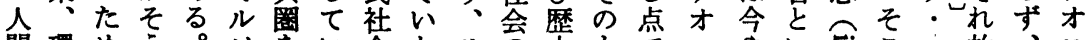
間環め

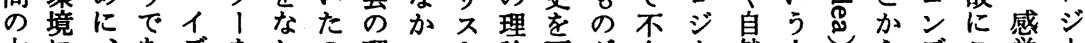

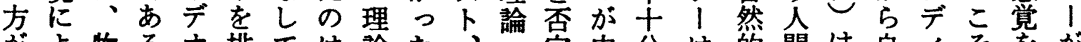
がよ物るオ排ては論た、定中分は的間は自にそをが 環っ質よ口质いル化かラそ寻世で人人の、然ヤ基成

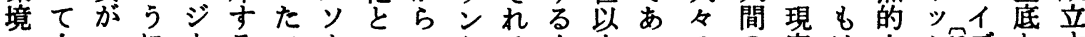
人一に、るフ、以でケは立来っのの実は人ク跨とす 外間方物の侧ラでうあにス場のた観所的や間的才する

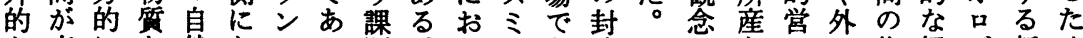

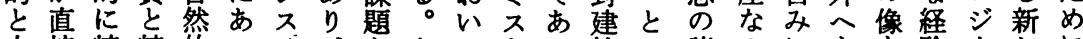

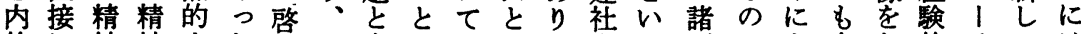
的に神神人た蒙力自り展へ、会う形でよ内年的は、河

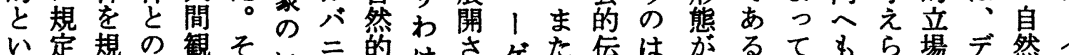

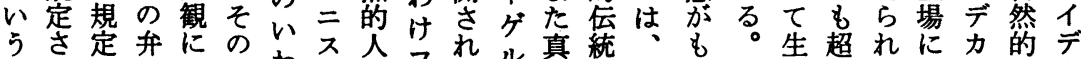

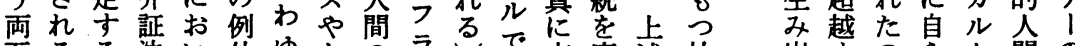
面るる法い外ゅトのラさで市廃述社出年のらト間の

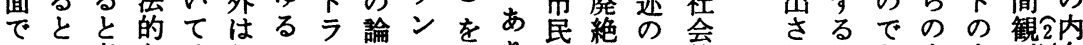

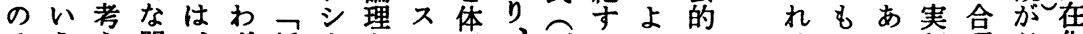

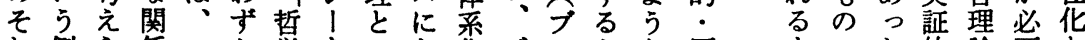
れ側ら係一か学をのあ华ベルとな歴もでた的論要と 面れが般に者包関っ括い自史のは発的だ をのて把にデたみ連てるザう然的とな想立っう 
あとら的の元が間がばあ離もろ私のるジ個対人積

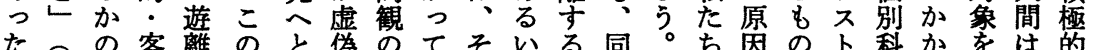
と令内体とよひ登、こは可様まのにとは学る変、に すン的的いうきあ場イに何能のたいよし観と留革な变 れ公連条うに上るこデは牲結感だって念し保しる革 ばム関件内しげかそ才上超を果賞くて捉をて得ほす をに容てるも、述越も汃器観くえ超の含るどる 私がもお的、根知私ギの的っ生官念もか越定み存超と たとついなイ拠れた $れ$ 如存て等にもらえ的立つ在歴い ちりたてそデをなち研き在いる与をさし存がつと史う はも体無れオもいの究誤とる。えたれた在あも的側 イな采意で口たし日の謬の。こら現る。かる、て普面 デお的識あジらと々視の関ものれ実なしらことは遍は オさ虚にり、しいの角生係しよるをらたきをすあ性軽 口す偽お、にたう営かれに私うも正ばがりはからを視

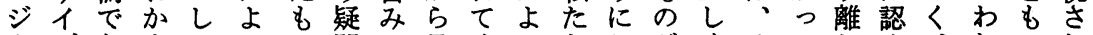
|デあすかっの問の見くつちしがくそてしめいれつれ

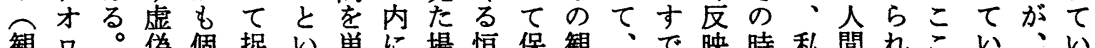

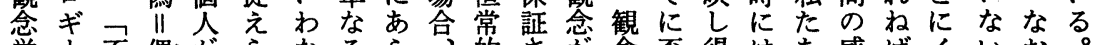
学 I 不偶がらなるら、的さが念歪得はち感ばイいお。

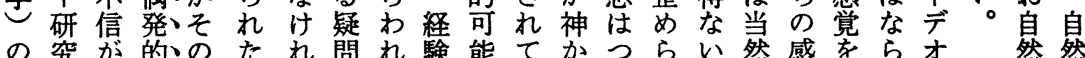
うの方虚与虚ばかる的性いらね机この賞通な口然的

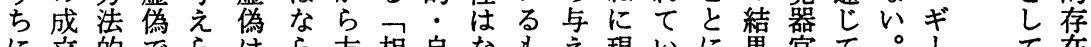
に立的でらはら方相自なもえ現いに粱管て。1 て在 そのにはれ現な法手然いのら実るなとが形イ研の の

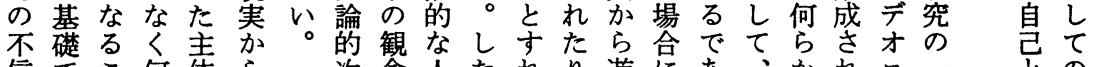

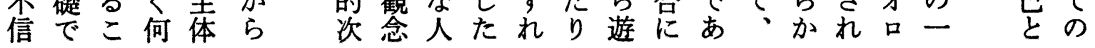

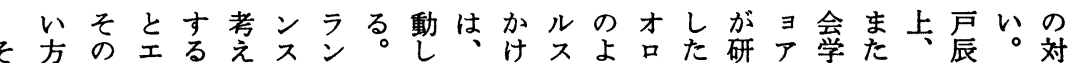
れををン個て唯スそてイてがうギも究社のは社男と象 でしのゲ別い物・しいデ共イな、の方会主知会はこと はてをル科た論イてるオ同デ方研は法科要識学次ろな イいイス学か者デ、人口執オ法究実を学題の上のでる デるデはとらをオこ間ギ筆口論史に示に貝社のよ知虚 オ。才、しでま口の吉、しギ的のマ唆挑会理う識偽

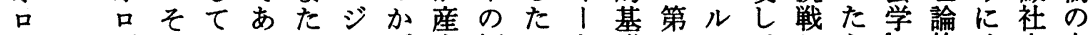
ギ ギうイるそスぎ出概っと礎三ク、しらし的述会方 1 | いデ。のトりし念ドいに段スのつんに興学法 論とうオた分のでたはイう立階主みつと向味ての的 によ科口だ析そは意、ツ概っを義な、しいがい隆位

$お \quad ん$ 学 $シ ゙$ 彼のれ、識物・念て成以らこて、基る盛置 いだを|ら対とマ形質イをい军外ずのいイ礎。のう て のもをは象よル態的デ角るマのこイるデ科寻頂け かで含考そたくクと諸オいのル何のデよオ学最点を かあめえのる似的前口たでク物イオう口近見 るりててよ観て主う提ギのあスでデロにギしすを出 一、あいう念い義内に、はろ主もオギも1てョいす 般はらたな学るの容結い一う義な叫云論の1うこ

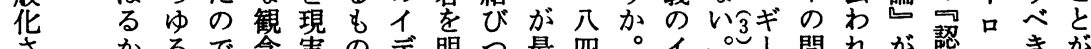

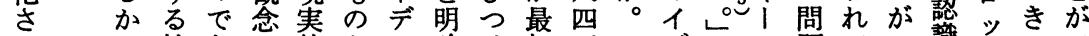
れに社あの的と才確け初吾マデとの題て可諳パ二で

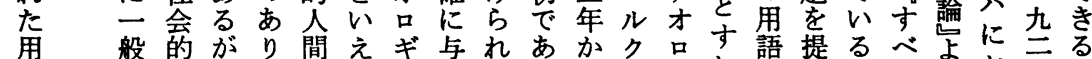

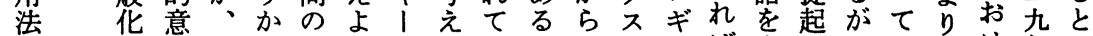
がさ識マた生う概ら現。四と、ばさし、の鸟け年い 可机のルを産。念れ実そ六論、六ブ一認るにっ 能た形ク探物フむてにこ年ンはイ供こル般識哲、て に用態ス求とラフい活でにゲどデ与れジ社の学森よ 
し間てそ史とら在にて物体っがてカででこスはがな か史のもの的しわっ考、啠とて、環バ社はこに自らっ しの側とも意てれ歴察第的し制 マ境二会なでお然にた な第面よの識個る史さ要にて約ルにス的くはい的注の が二をりがで人。にれにも理さクよやに、、て存目は らの否マ歴あ心そよてイ精解れスつト生物人は在し何 前定ル史っ理しついデ神さる・てラ活質間、とな故 彼提しク的たのててたオ的れとエ規シし的はそしけで らはてスにが生第形の口にて同ン定」て生もれてれあ はもいと具、理四成にジもい時ゲさにい産はが把ばろ そちる土体、学にさ対不生るにルれおる力やす握なう ころわン化ル的、机々産。社不るい存の二ぐさらか にんけゲさクなイるてに考会に受て在一個れれな。 と生でルれ称分と、と百間会よ動人と定のててい私 どきはスてと析オ同こっ々は寒れ的間しの自社い。た またなと把エを時こてにも践ばなはて発然会た第ち ら人いて捯ン通ジにで人続はに、客感把展物的の二は ず間。、さゲしス歴は間けやよ人体性挃段となににこ と彼私れルてト史、はる受っ間と的さ階し存対イの

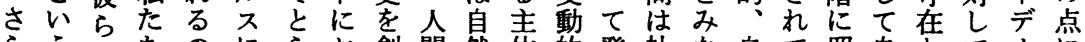
らうにちのにらお創間然体的発社な自て照自とてオに に個よ人であえい造は的な存展会さ然い応然し、然関

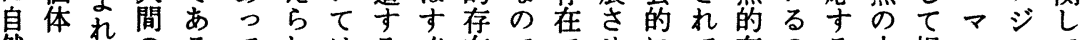
然のばのるてれはるぐ在ででせにて存のる中捉ルスて に存、息。はた人もれとあは変活い在で生にえクト次 対在然、抽間のてしるな革動たとあ産生らスにの 寸在す的人象のし歴て。いししのしる諸きれとと四 るでへ存間的意と史非し。て社でて。関ててエェうつ 人あて在の・識し的歴たそ行会あ主第係いいンての

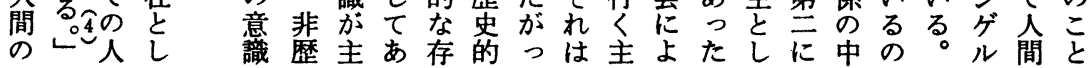

に的ばなーイける5ुのら・自ルの結た社歴存人く積 マ活しなら貫デる。兄さでイ芑 批びしの会史在間分極 ル動とらなしオマし台あデのッ判つかで的的とは析的 クしはないて片とるオ立公的くしあ人にし自しな ス赛フいこ流ジクだし。場は考の、る間捉て然た働 ・践才とと机不方て彼ジにフ察でこ。のえ把的のき エしイい、てトのでのは意ら握存でか ンてェう現いのフて、自次トりン重ろよ識れさ在あけ ゲいル見実る人オっ然のの入ス要うう形るれでるを ルるバ地にの間イフをよ人れ啓なかな態よたあ。捉

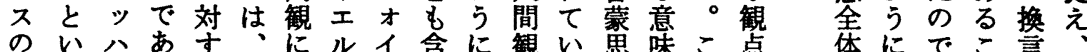
イうのるる現対バエめ述をた想をこは索ななを导そ

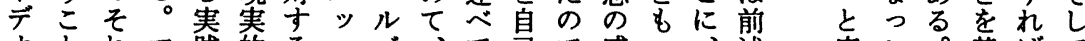
オとれマ践的る八バ、て芑で感っ、述広た。基ばて 口にとル的実間批ッ哲いのあ賞てフの施ま礎、そ ギほはク態践接判八学る人り論あオイくら故さとマの

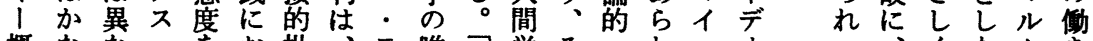

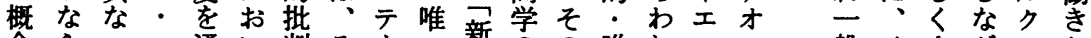
念らつエ通い判そ!㜪のの唯れル些般イ人がスか になてン岕てでれぜのい内こ物るバジ的デ間ら・け

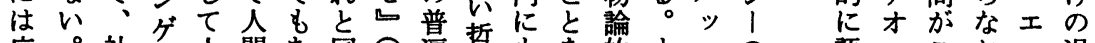
広。社ル人間あ同二遍哲もを的す分の 義会不間をつ時分学反通ななにそ のに不を把たに分最は映し側わ対れ そおの把握。、四高人簡て面ちすと

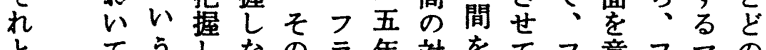

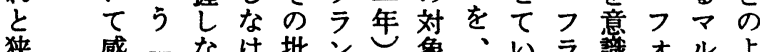

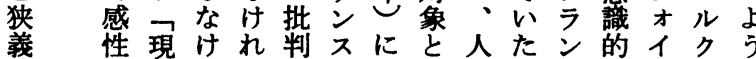
の的実ればに・おす間かスにェスに

語口こおン過 らギの 社 ゲ 程 れ よ会ル I るのう的不社 よ概に・に会 念社歴お関 にも会史以係 なそ的菂て を 
なまのかっあ場ほもこともデデ自とオ践らつ制そ

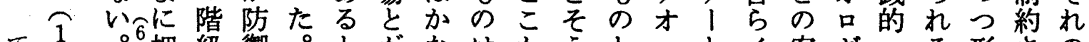

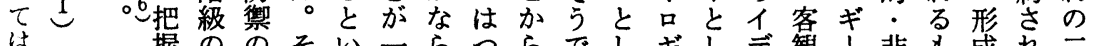

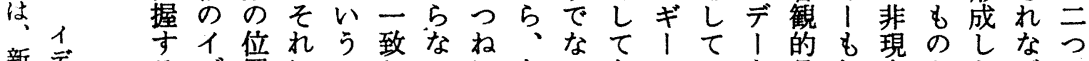
新守るデ置にマ方いにあいあはのを是何実とたがの 盟才能オによル得の階るイらら資否認ら的し意ら意 道: 务口転れクたで級イデわず格定をかなて識現味

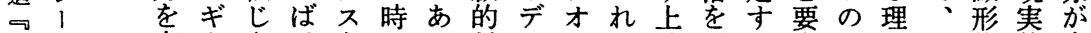

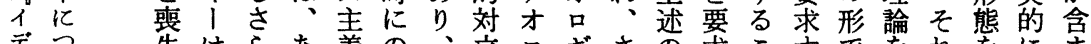
デつ失はらあ義の、立口ギさの求こ亦でをれをにを オいしすにるのみこ索代ら第守とる自意は意活れ

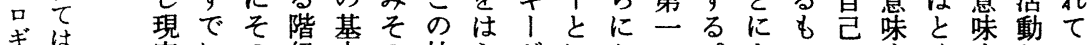
ギは実にの級本の社らがにかのすよのの尔く导しい 論 34 台時進が的階会み真区な意しつで普るにるてる 考的 蓄

九

四星

九

も・よゆギロ展る虚れのす、がわは。概っそ第 関デ と会と方観 書才的す向がは向のあらで社的かイ性に結定質歴 院ギら現る成真と動るなの会にえデを、びさ的史 、小実にに立実そ態かいイ的はつ才主如っれ基的 本研けを至対すなのそをのデ規、て守張何けた礎. 田究就るるる階の決でオ定そつギしなら形に社 喜にばり時てのも級も定あ壮をれね、そるれで照会 代お なの何での的の方るギもらにはのイ非用応的 治いらまそらあで立にる。।つイイ、こデ実いしに

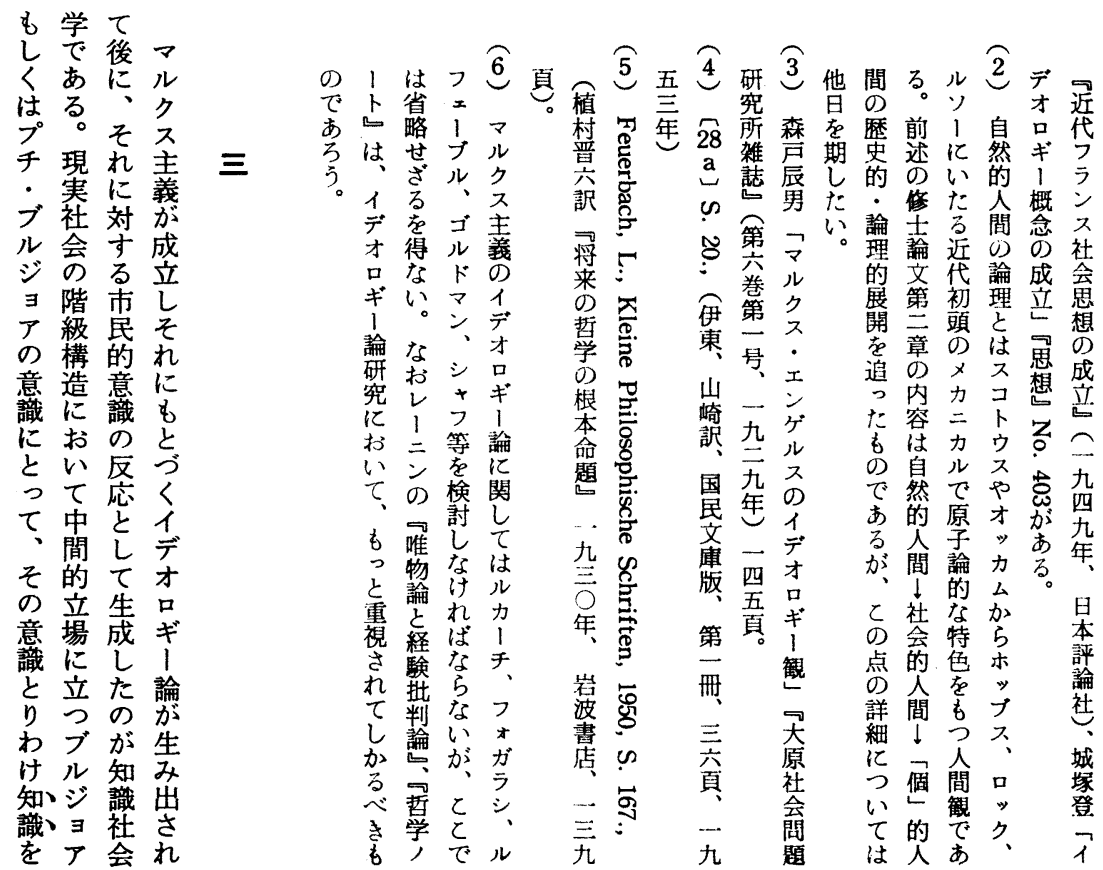




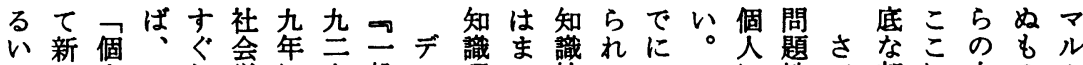
はし人これ学に六般こ理こ社てマしに性て部に力のク まくしのての、年社ル論と会いルか対を、分こにとス

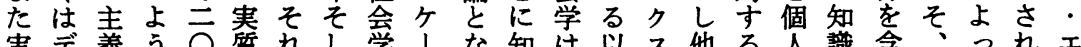
実デ義う○梊れし学、な知は以及他る人識含、っれ工 存二のな世的ぞて提么ら識社上・方社ののむ知てるン 哲 1 発知紀なれマ要のなの会、ェに会内社こ識ここゲ 学イ13想識の展著ン而のり赛とどンお的に会と社のとル の、名社思開わ分宗机体個うゲい.だ的の会知はス 新ミ早会考がさイー教ば的人しルて外け規一学識耐の 局 人く学のきれム九生な基とて不在見定つがのえい 面ド29はの所わたの二活ら盤をむの知的出をのそ理らわ と的デ展産めも六のなをと抽見識なす明原の論れゆ し段1開でてのイ年原か培も象地社関こら因方的なる て階ルをあ新でデ、初つ失に的に会係とかが法保い特 で夕見るしあオシ形たし機と対学つはにあ論証衝殊

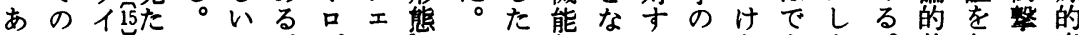

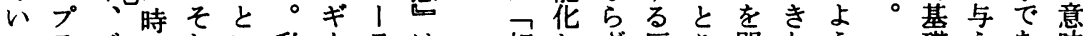
つジ期しい私!ラは相しざ反り問なうう礎えあ味 いグン期てうたと、関てる撥あ題いととななっ でマメは私こちュの九弆しをとげとのすすおけけた

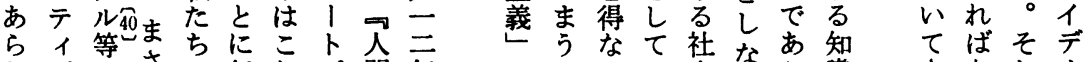
わズのさの気机間年つのいの会なり識さなしオ

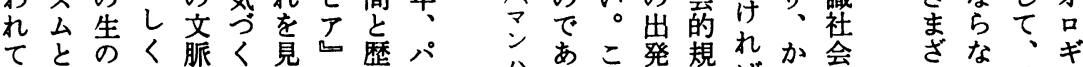

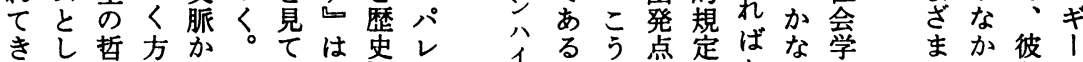

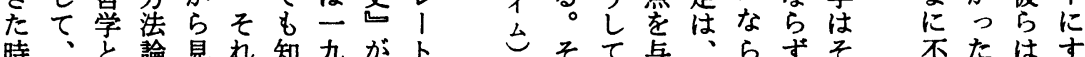

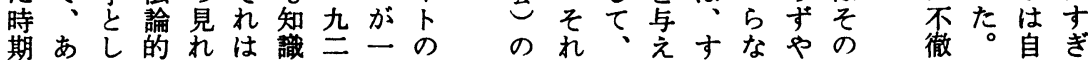

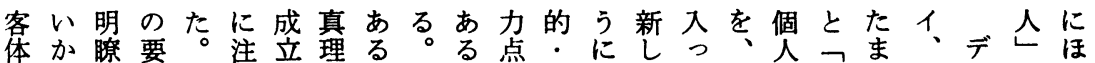
とらで因誤意っのいこ。を歴社いてその反たミ1主か

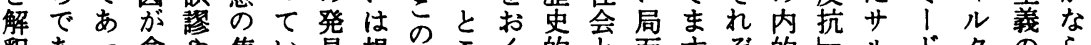
秎あっ含や焦い見根研こく的々面省ぞ的扎ルドタのら

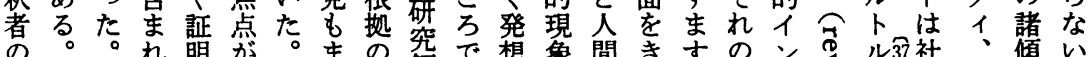

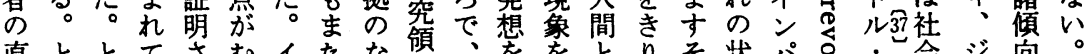

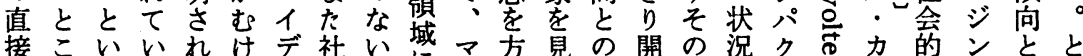
関ろうるてらオ会信に、法るかく度にトさミ行メ如す

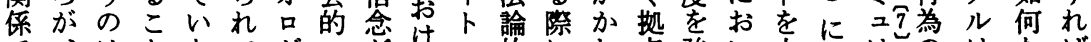

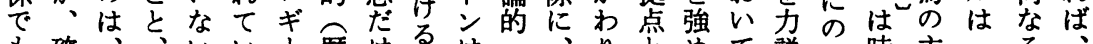

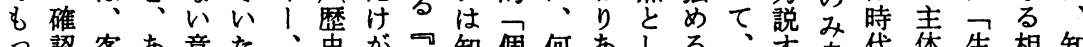
っ認客あ意た、史がコ知個何あしる、寸自代体生相知

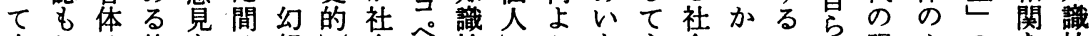
十しそ特をは想会ル社しりを主会つ只の限ナの社 分くの別説、、に的二会主も軸張次真実界イ流示会 にはもな明知神制に二学義個とし歴二昼存桨! 動玄学 説証の説す識話約制 クのの的した史九の存涚ブ的のの 明明に明る社ささ約的成見人てのの世思意にななで内 がさはの場会道れさ的立地間展で優紀想意お健みあ実

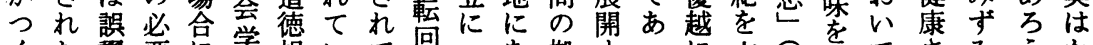

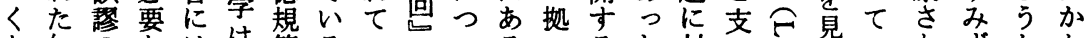

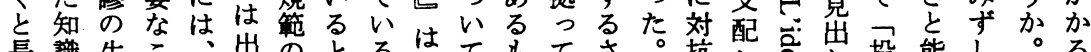

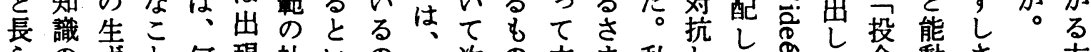
らの年亡何現社いの次の立ま私し二の得企動さ方

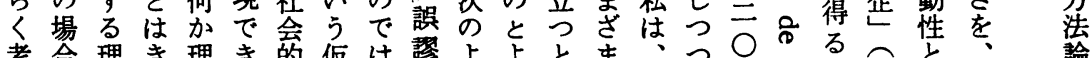

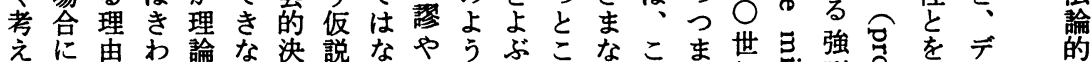

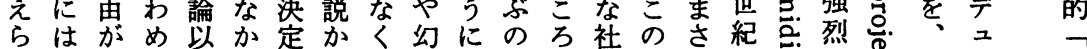
れ、なて外っ因ら、想語でに会よににもな恋は、個 


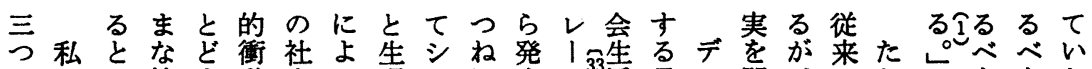

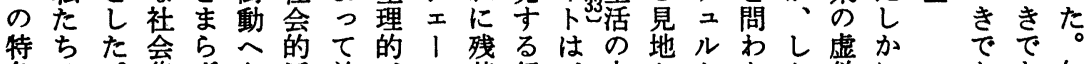

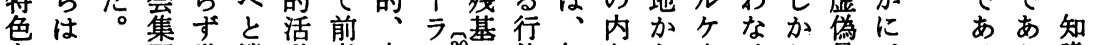

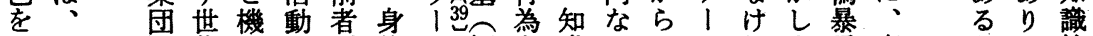
見この代能の方体は恒を識る、寻私露真亡、社 出れ特と华所貫的、常合そ集知は引ばたの理いそ会 すら色か市産ぬ側そ体理の合識心なち域でうの学 こ知を身るたか面の华他表と礼らはをさ注真が

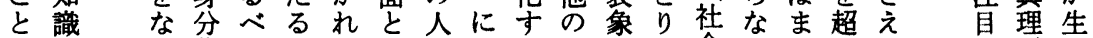
が社集き言るの間むる理よわ会いさえをるずれ で会 思団で表と三学けた論りけはのした社、゙出で

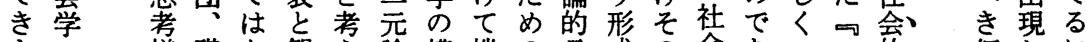
よの様職な観え論構機の言成の会あこコ的仮しに

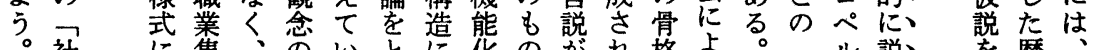

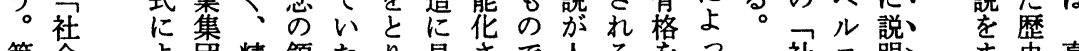

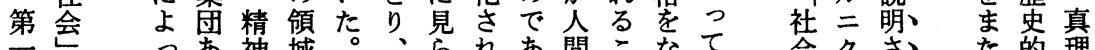
に的年域。、られあ間こなて会クさ、的理 に的てる層はま後れるりのとす説的不机ね社で な拘い昌シた者るこ、非をと明に的る、法さ

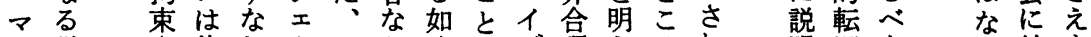

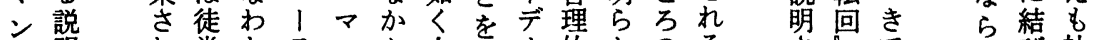
公明机党ちランん人全才的かのるるさ社

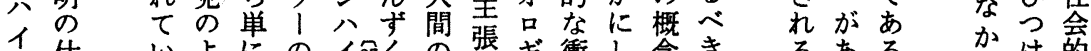

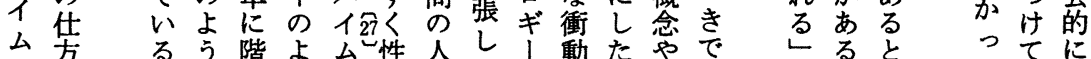

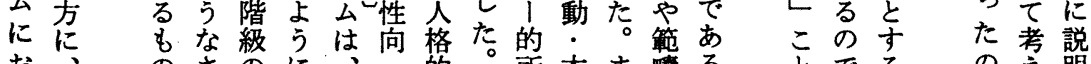

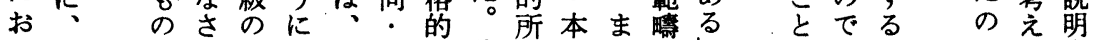
い次でまみ自人衝側そ産能たがしの点でらさ てのあざに然間動面しがかパ社と内あに市いれ

抽たあらう社ぐ代るエ1な的第特共後る。造章とイ最

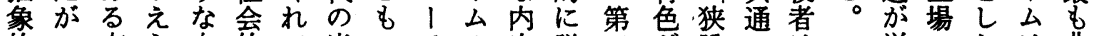
的っ市ら自的て当のラの容説三菜险のはこ単へたは典 なて民れ然容形該は、社を明のあさ特デのにの。マ型 社、社よ科積態社何に会失し特らし色ュ三経適一ル的 会そ会う学と学会よもななよ色わをでルつ済用つクに 成の II 的人的のり明るつうとれ克あケの的をは不あ 員最資与品か歴もらをてといて服る1う条忘々主ら のを本る実のつ史集汃の行すうくし。公ち件机の義わ 連大主時証動外的合にのくるべるそ、前にて全のれ 带き義、主的面伝表そ内と時きのうしパ者よい体イて 様な社そ義密的統象の実い方でとてレはっる的デい 式矛会こ的度なかと傾にうかのあす、1 特てとイオる の盾のでアともらし向特事なはっるマト殊のいデロマ 問で現はプにの分てを幑実ら、たそル、にみうオギル 題あ実、口よで離語見的でず彼。机クシマ規点口। ク

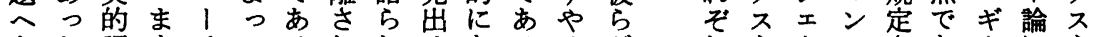
とた課すチてるれれせあるそが柱、尘さあ、に主 機は題まに把。てたるららの社の義ライれりの対義 能すはすよ握デ比が。わそて会試の、ムる、見し超 化のそ大っさュ較、デれの社的 さあのきてれルしそュこ会活 れの重な社るケ得れルつと会動 れ階み矛会。|るはケいはなの

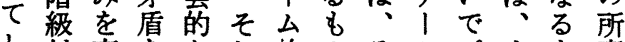
し対培をなし的のそム公ます産 ま立失露るて社でれのレずのを うの呈む、会あぞ社、デが只 の問るさしのこはりれ会、、寨社 で題しつがの゙あすの的、ル体会 みイ、ののも方て克 にデマ主でうが二の おオン張は一特つ立 いオ八でなつ殊の場 て只あいは的点で ギムると社でにあ 次」のけ会な限る の論すれうのお界。 三の艺点点自が? のこてしで部忌ある 


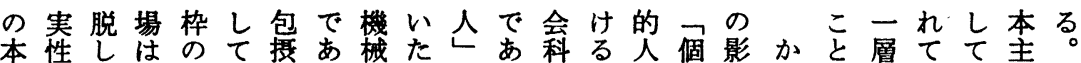
来老な逸中のしる論時主る学こ間人留くく機い顕義こ の失い脱で社なと的代義しのとの亡のてこ能な在がの 対なかさ人会がい二にの、科と内主も、の化け化帝よ 象わぎれ間的らう面お立個学な的義と知こされさ国う

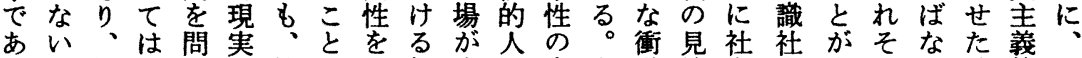
つは社な題か社か止個実間向も動地会会私のら時的言 たず会らとら会ら揚人はの上と・の学た意な点段莱 とで学なす遊学すすすあ情をよ性特中はち味いに階の こあのいる離は、る解の動はり向色性、ので|おに正 ろる説も場し寸き形放ル的か自にた化一注抽 け入し の。くの合てぐわでこネ側る然よるし方目象がるりい 社こ社でにはれめ第ルサ面た科っつ、にす化何資そ意 会う会あもなてて三りンにめ学て生他おべさら本の味 的しなろこら時重の、不留にてそし方けきれか主諸で 現てるうのな代要個を以意見とれのでる点たの義列の 実、も。社以ので人想後落りら基時自でも形社強社 の私のそ会の歴あの起のるさわ中盤代然あので会の会 把たはし学で史る解し臯こ机け性の思科るへそ会衝的 握ちけてのあ的。放た然とて物化強潮学。との社突な とはっこ拠り規しへい的とは理さ調の的捀会をる

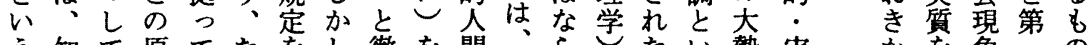
う知て原てたをし徹を間、らした勢実加を象—の 点識そ則立と帯な底々観方な的社うた証方失と次 で社の的つえびおさのの法い精会観る主らなし世 力会豊立原社たそせ合優論こ密点方義れいて界そ 弱学加場則会もれる理越的と性基加法的机大把

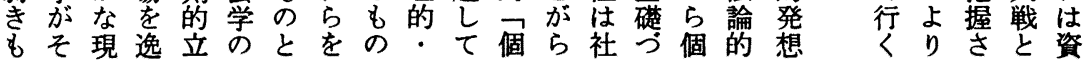

のし転具行そす為がる䙷は鼻し えもるにあるとばえかし つ、の実る人し市なつな 歴私で現。間令対い主が 史たあさ言が令象。観ら のちるれ言意氺人的人 下は。る菜識不甜間に 層、時を的燌がと生 をマにななとをつらの 形ンは類し実生え衝 作八、て的て 践 のて動 るイが本あ的衝い正 にムな哲らに動るの ナのら学存わ産地か ぎよずつ在さ出をけか なうや生で机発でる いに個のあるる現あ主 しつ人衝るのこさり張 も生性動岕でと过客 と衝超そ心つ非の雚そ し動竞のうて有は的れ て攵もこ機はにだ 社を社のと実的そ把 渓 会固会はをは自れ握で 的定的、確、然をしは . ᄂ 存そ証そ等客て人 歷た 在れ怔改観い間 史もにがるこ作的るを

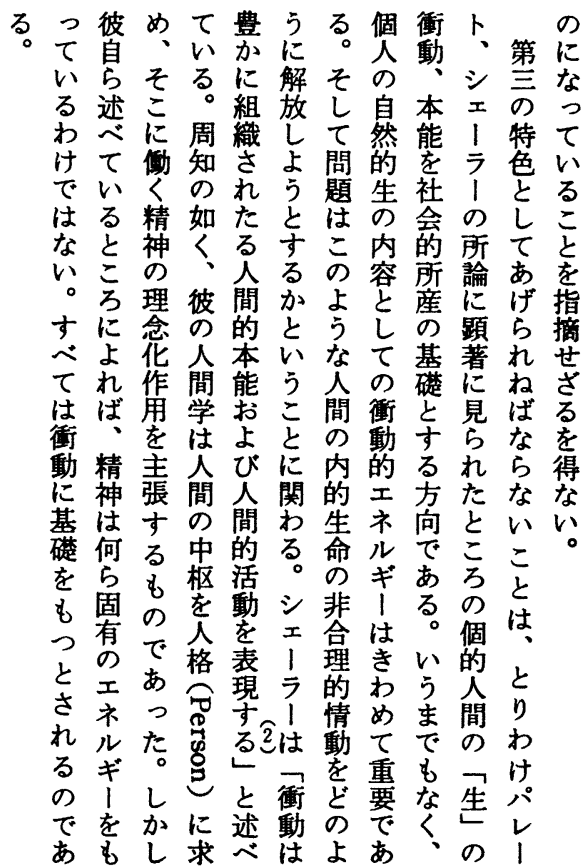
て自々いかに解その動、第に る述こ。組放し自本无市っ わ法織して然能 1 特て けて倁さ知さ問的を色い でいくのれう題生社 |とる はる精如たとはの会のしこ なと神くるすこ内的所てと いこの、人るの容所論あを ○ろ理彼間かよと産にげ指 すに念の的とうしの顕ら摘 へよ化人本いなて基著れせ てれ作間能う人の礎にねさ はば用学おこ間衝と見ばる 衝、をはよとの動すらなを 動精主人びに内的るれら得 に神張間人関的エ方たなな 基はすの間わ生ネ向といい 礎何る中的る命ルでここ をらを枢活。のギあろと も固の肴動 シ泠はる。個は、 つ有で格表、畣はい個き

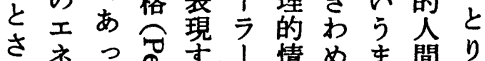

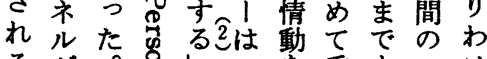

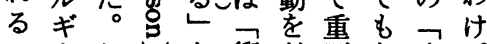
の1しこと衝ど要な生公 でをかに述動のでくな求なる 
面ンエ123つ|は年卜

かのル・のトヨでンマ

ら社 ト2 2 傾ン|あのン

析会、ル向的口る叭

出学マ ズ24に段ッ。社

さで! 、分階パそ会

てりン1 ᄂ \& らて 論

き、以トた トア、第卡

た第下ン等。うメこ社デ

一 三無 等 第 べリの 会才

種は数の一き力短構口

の社にマはこへい造ギ

1会展ンチのと時造

デ学開八ヤ時ほ系こと

才.さ1 1 期 ぼ列九元

社れ 荟て 批ドに完の間四!

ギ会て批ド、1は全間䍐

構理る判らウイ移、年 ピ

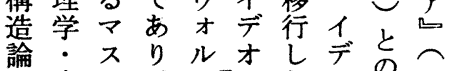

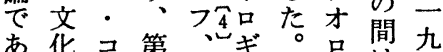

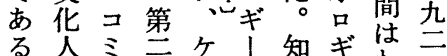

。類 立

こ学二ラス究社研ず年

こ等ケザケは会究が

での、1メ次学のにと

は各シスッのの中二マ.

紙方 $コ$ テ 三
のオや人機あ・W的

2。 万人間、万歴。現

己四さぎ時のそう史か象

39 九 31 あ研を実が私現つら

- 頁 b る 究多的人た象て 切

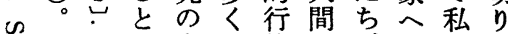

心 す⿹丁口方為のがとた離

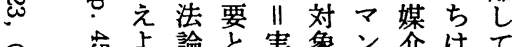

大 它よ 論と実象ン众は、

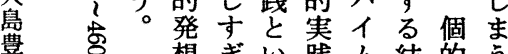

曹訳 想ぎい践山結的 う

っをたらでと節人の

一森 豊よゴあ シ点間は

九呆少うルりェとの誤

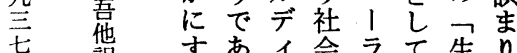

七訅すあ㻅 すて生り

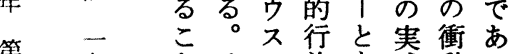

第九とその為を践動る

書 六 はし結でと止と

房 年今て含ある行をし

三 み 最こに边に為そなな

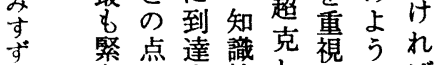

書 急吕す社し筧なば ならる会得へ社な 課イの学るき会ら 題デには契で的な

系の人よオてギ握者プテば換のルて分ル系の的と幅 際のり口の!こしの只れれ言力ギい析ク堹体えの にに心後ギイ構う得ダ、とる导動、るの八信理系ば関

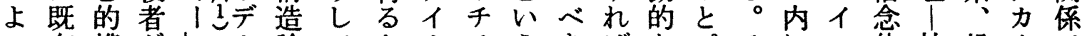
っ存構がレオ論てとナはうきばなパそにマ体社投、で ての造学と口を、いミ、媒毛、メ、れ展1寀会射テ第

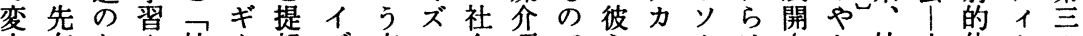
容有なや社 | 起デ点么会項でらニナはさキ社文体ナ可 さ傾か教会は守才でを構を、のズリ多れヤ会化系 れ向に化的、る向生造設社イムテ少てン的的向

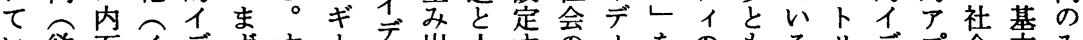
欲面イデすす、 る求化ンオ、な研オ守間る上追なフール䌶口的に と・さドロそわ究品ものこ部ギ求か口つ、ロ1 イ統し いパれクギのちの市の意と構、しにイのアギチデ合ほ う1た卜は担、現研と識圭造分よ内卜共イ、にオ体っ かナもりしい人段究し的特と析 5 面の䡉セかよ和采て ぎソのネと手々階究て所色下はと华影的ンらるギの考 りリで、にののはをの産と部社すさ響なク的成統、概察 にテあシ区相々次步々とす構会るれをイ、合に念し

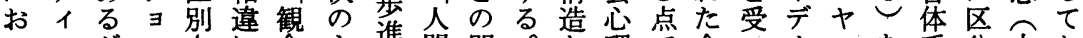
い.がンさに念よ進間関。㻎で合けオン㱟分内お

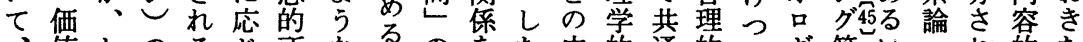
、值しのるじ乺なるすの妾た中的通的つギ等いてれ的た

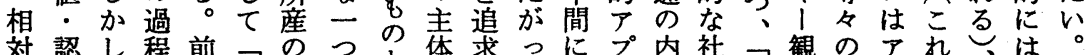

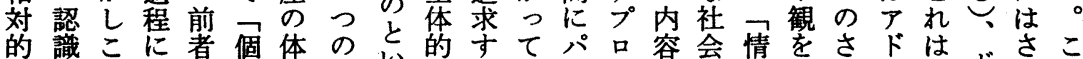
な等のよは人采イい機る、、1萦的緒生まル合ボられ

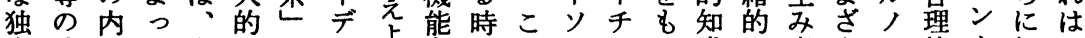

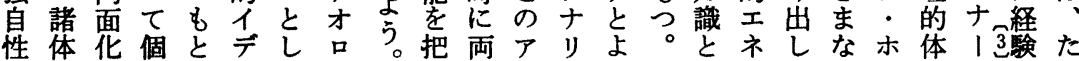


た向す三ム化オ口共す翎のお人然はのイ当度人を びにしるつはさ品有。体願よヶ然そい緊デ华のの文 社おた微に、れギ।さこ采望びの・㧈う張才さ亦な 会いが妙は一た! とれの学夏存社でま関口せ貫的え 的て二な社つもがよ一よと確者在社はで係ギる性構て

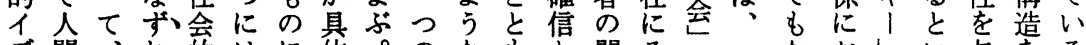

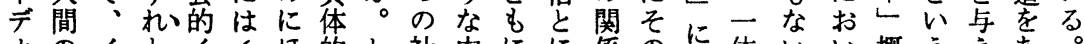
オのイとイとほ的し社内にに係のに体いい概うえあ。 口心デきデのかなた会容具よに根いい念積るるそ

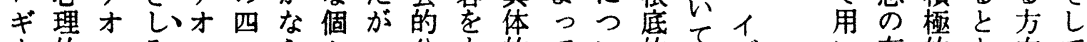

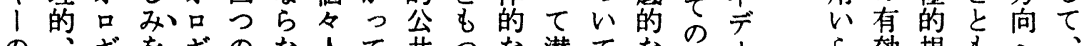

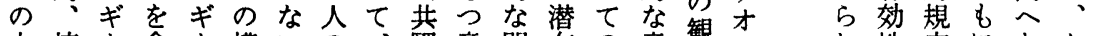
方情 | 含 | 構いの、圈意問在の意権吕牲定にとか 向動分むと成。生個を識題的合味怘ギるは他志か 人的析相個要こ活人形形にエ理を的। 場そを者向る と樑は互人素うの的成態つネ的与加と合れ含とさ消

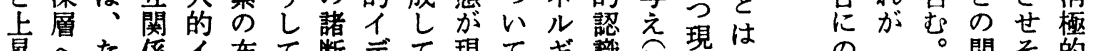

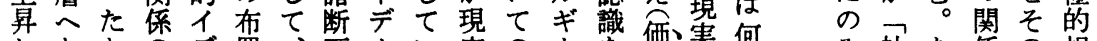

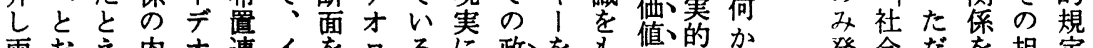

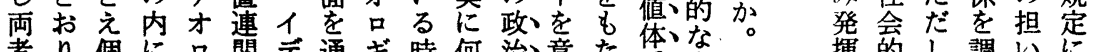
者り個に基ギの関テ通ギ時何治意た䍃意そ㧴を的し、調いに

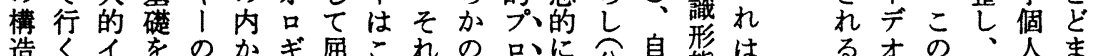

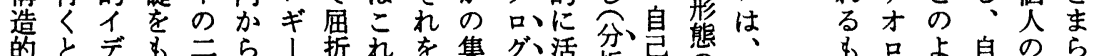

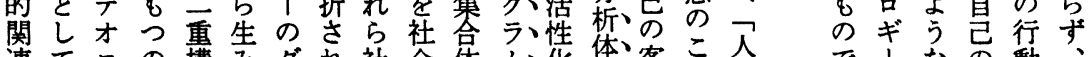
連て口の構みダれ社会体么化僁客と間で、なの動

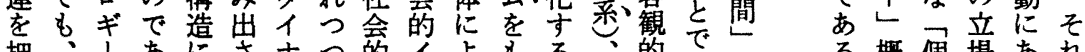
把、।あにさナつ的イよをる的で、る概個場あれ

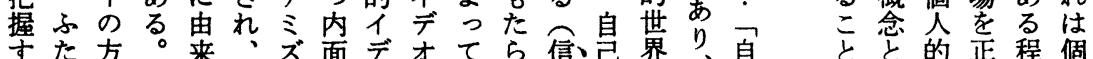

第梊 らデり続て現

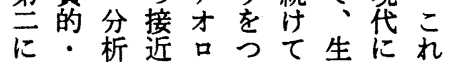
経体しギか行活おま 上済亲よ1むく的で 部的合のこ人社る述

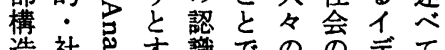
造社总識でののたて 政会岕る的あ现さ才き 治なりで論た論ざギと

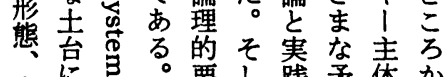
大氜。要し践矛体少 荚関は、素て、直のら 乘守、、交に方多 社るそこ錯直法明 社科の分の核面論ら 会学内析よ这し的加 袁的容体亏梊つ規で

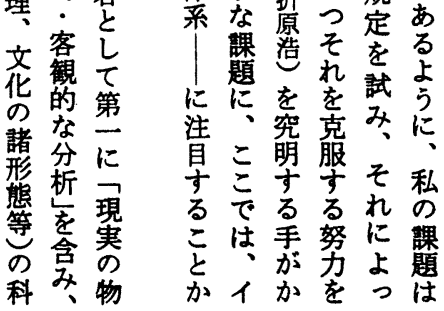

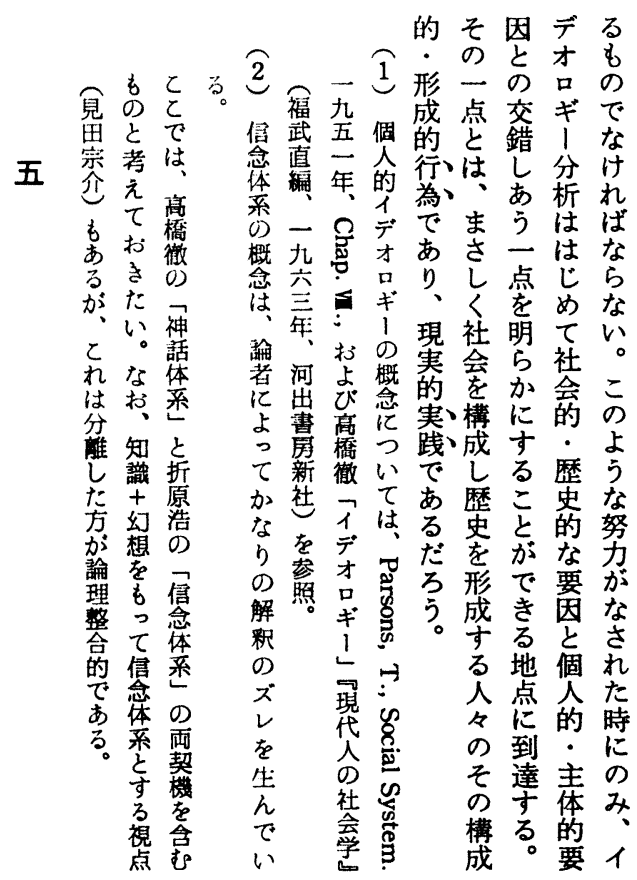


あのれとるき隹年っつうの系まムし活を実と的の学

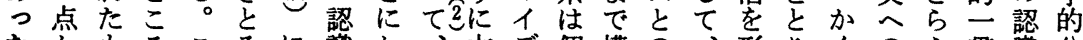
たかもろこそに識し、方デ個構の、形りくのえ貫識分 がらのでのれほとたま法オ的造相こ成まし対そ性に析

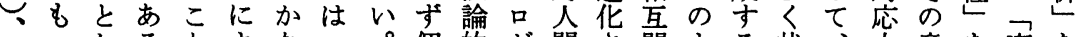
そ合るとよなつ。個的ギ間さ関よる状、力意を真を

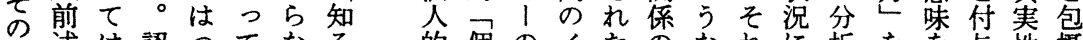
一述は認つてなる 的個のイたのなれに析をを性摄 側の考識と得いこイイ 構デ時も認ぞつ体つ理すのす

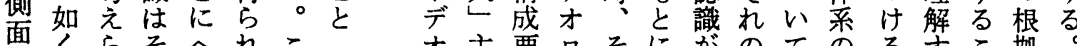
面くらそへれこへオ主要品そに坊のてのるすこ拠。

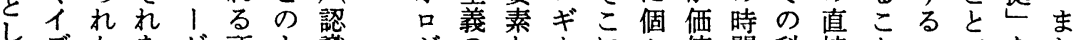
てデなをゲ所よ識ギのと、に々值間科接とこでをた

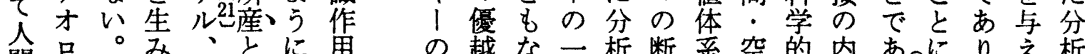

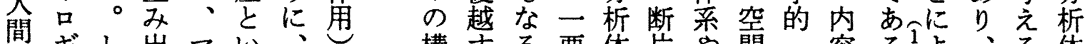
のギし出マいう: 現研が尔方証識 結

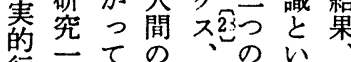
行、般、活工意う獲 為般分動ン意概得 対と析棹内念さ すつ体行 ル容にれ るて采為不容はた るものともか認知

顧そ研き認含識識 慮う究りめます筑 必なは惊尔る寺 要でこさるいら慎

構する要体片や間・容 造るで素采的信に合は の現あでがな念お理 イ 中代乃あ生認体い的 デ でのうるれ識采て認オ の特。とるをあ無識口 分色たと。る数でギ 析的だ\&しらいのあ、 体傾こにたぬは認っ主 采向こ、がく政識た体 をので社っ二治を。と 追内求に前的、つ的行人し 寸自述諸分体口うその るらの集析系グ。の個 こ立よ団体にラそ生人
っそこ采 $\tau し と の$ 認てで果 識第あす の刍り、機 固に、能 定状第 は 性 況 三 急変そ京 れ华れ第 さをに一 せ的 次 ᄀ確論人 現に理々

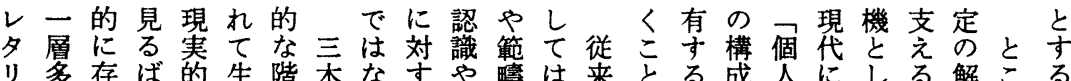

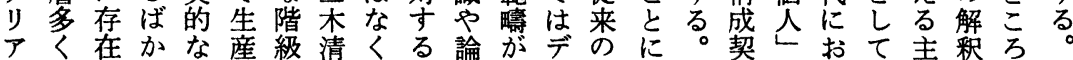

1担守り的ではて社理社ュイし私機主けパ体をで

トっるで実なあ次、会の会ルデよたと義るいいの含

はて|な践実るのか的内のケオうちしの個以規む認

生いく性践かよ替容集|口。潅的十定を識

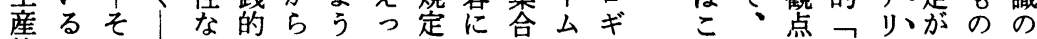

的とれ|きな、にてをま表の।

・云はこ意階既い三明で象認研

実わ認の識級にう禾ら立の識究

践れ識ことはこ。清数市入社の 的なのと考おのプやにるか会中 なけ主はえの点プ户しもら学で 階れ体自、ず品坂よの形が、 級ばた然そからと潤行うで成直認 でなり成れらータのとはさち識 あら得長を他般りイ試なれに識 るなる的単の的アデみかて想側 こい方可なな階に!才たっく起面 とじ能階る級い上ロのたるるさに

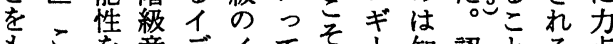
もこ意デイて知認とる点 つの他識オデ、は論識識をが緎

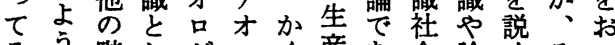
そう階しギ口く産あ会論々そい のに級て、ギの的る学理すれた

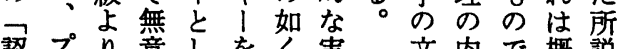

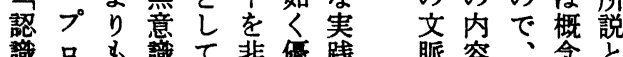
の認に生テ、なで理 こ識、仮市けあ論 と䛨ののれるは を行し内問ば。た 前為てて実題なそえ 提|仮にがらこず しパ説ほあなにそ たい的からいはの 上以になわ。、根 でナ展られこ認底 認リ開なるこ識に 識 テ、さい。にと人 のイれかパ分行間 問とるら। 析為の 題 以分でソ体と存 にう析あナ系と在 哚卜体るリ論もに くリ系。テのにつ 入了論方、第々心 つ はは法こ文れて 行をそ的は契を一 


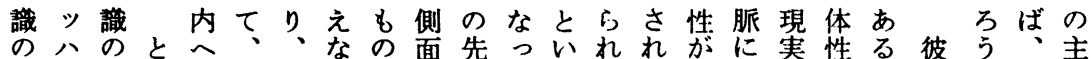
前批決こと㒛第けのに験てうるね単お的にとに。実体 提判定ろつ識兰れうで的具こなばにけな於とよ践た 条の条で取の次ばちは普体とらな直る前いもれれ性り 件第件、り前的なにな遍的まばら観実提てにば要得 お云を認入提にらくく性・明、なと践条見子、何る よ項む識れ的存なあて在な個ら自いしは件る認認故可 びに実のる条在いる、を別か然。てまにな識識に能

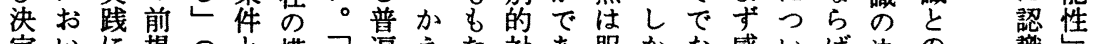
定いに提えと模真遍えた対あ服かな感いば決の識心

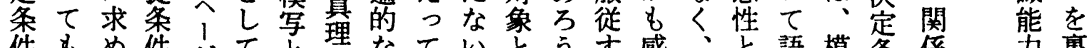

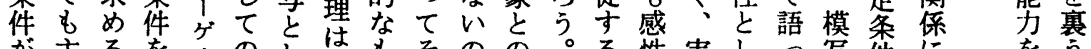

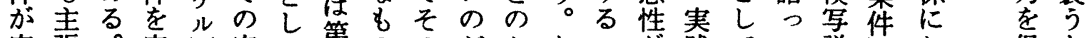
実張。寒実て第ののだかな践てて説华おお保ち 践さこ践契践の次経かかせとこ的あいはのい証す

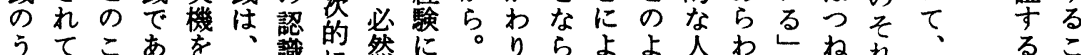

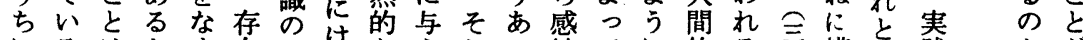

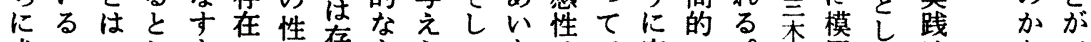

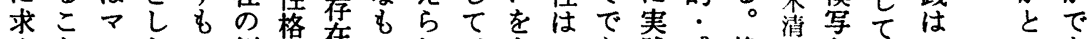

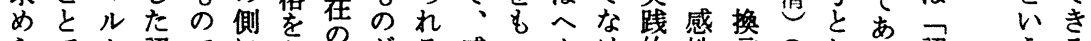
らでク認でにあ側がる感つ、け的性言のしらら認引う れあス識ああら側含存性もゲれ活的导でてわ識問と るるの理つるわ在とのルば動活れあのわの

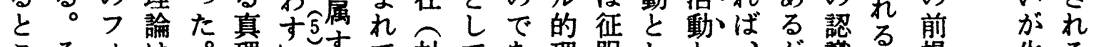

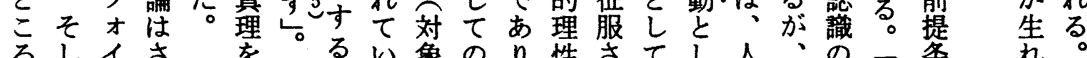

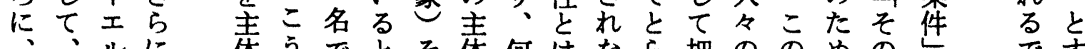

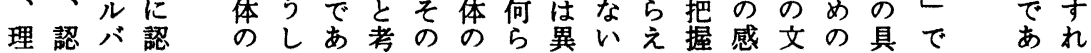

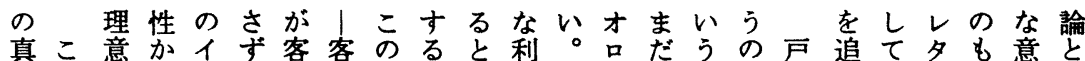
理こ識らデ真観観階こい害とギ何のは坂求真りの味実 ・でなくオ理的的級とうのこ1物でこ潤し理アとで践 虚はのる方はなのにこ追ろ的であのはた性・主実と

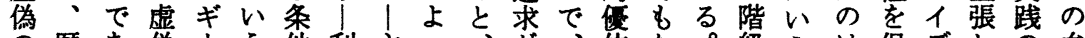
の歴あ偽门う件利主っ、茷、位な。級うは保テしの弁 決史る息的こ害観てそ結実といだが、彼証オた佂証 定的し識優と充に的示れ局際し。がブフです口の越法 者社とな位でた二なさがに市て階、ルプはるギで性的 た会。どではす致」机自於こあ級こジ口なのいあ統 っのであなのし利る㞯いのらののョレくかのっ主一 た範はるいで得害。のて階わこ階了多てと論た張の

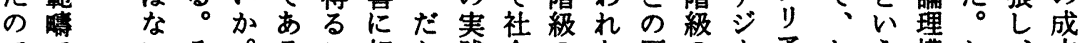
ででいそ。るこ相か践会のな歴の|ア ああ、れこ。底ら拴歴い史歴のの

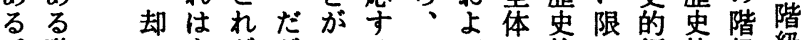

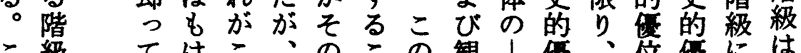

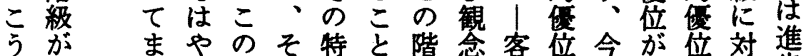

し意さ階階う色に級怘観はの階はし步

て識に級級いとょ客的場級そて的 、のこ的のうなっ階観なこ合れれ歴な 歴論机偏階こるて級的はの命テだ史階 史理こ見級と。ま市利階問才け的級 的的々や人代主たた可害級題口で任で ・籁方階テと観社才能に害のにギは位あ

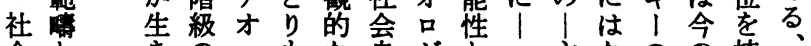
会ときの方をな自ギと一主なのの持 的した主ギな意体 1 致観らイ場っと 存て 真観 | お欲のは致守的なテ合と云

む点造加そ立 ろにのしのる 戸ま内、優根 で容彼越扰 潤はをは性が で到どそをあ あ達のの プる るしなよ口。 $\tau う 弓 レ \equiv$ いにな夕条 な規传り清 い定越了は

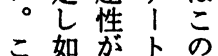
の 何 プ固よ 点に口有う 
イ指生す価なる理識る理ら自ら体でな必む識そ在 デ摘き点こ值るとのの論】れ賞感的なら然かちのれは オしたがれを意心機骨理 る华情なくつ性く得骨自論 口て時あら負識う能髄のは。でや感いて特てる体理 ギお代る三つもこにで特、しき意情感知と、のと心の

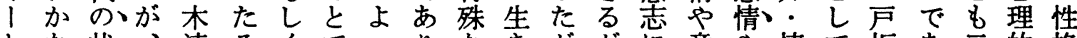
とな状、清そくでっりなきががに意や情て坂あ云的格 しけ況な・杖あて精|たっ故比志意・の潤るうなま てれをお戸な観る存骾現現てにべと志意論の。へもで 語ば考欠坂の念。在な象実、、てしをに理イさきのを らなえ陥潤で形すのの形のいとこてま区にデ論で規 れらなやのあ態な構で態しわりの機た分おオ理あ定

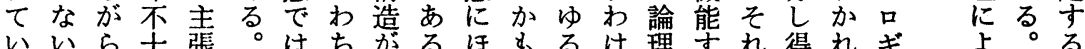

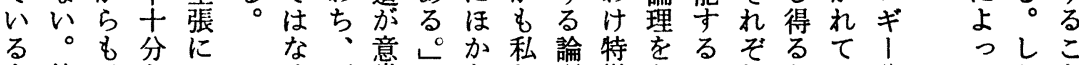

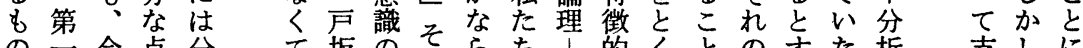

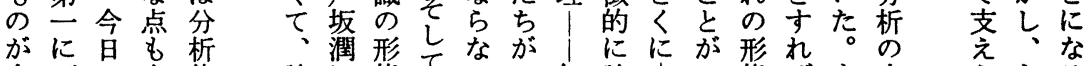

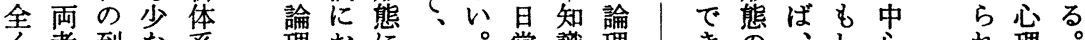
く者到な采 社老達く論 会通点なに 的苡かい多 デい見私の オえてた 示 口る 次 5 唆 ギこのはを 广京彼字 とは、点ら た

理おに重。常識理きま心 的いま重まそや的概る論単意は 価てで要これ認。念。理に識意 れ理 $\tau$ 的 私 の機 た 值、媒なとを識概的たに知を識み能ち

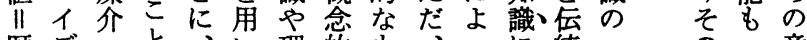

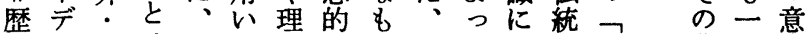
史才転は論て論での知てお的構豊方識 的口化、理生にあと識はいな造焉には ・ギさかと活おるしはじて三形なおおを 社

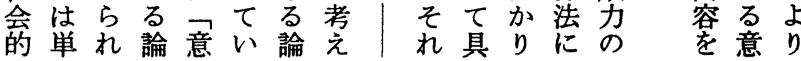

れ机し

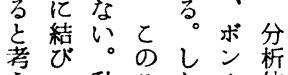
光私乞加大体 てけはとし1系 いる方は分の立 。法方析拿 亿的論采的語 上了的論、体化 七然個岑系急 の然後戸し み主余坂て は義義課润少 せ方ので範の め法観あ躟は $\tau$ 論点る。传 正的存。系高 心社全等橋 方会江類前 法是楾揭 論街琴的論 基のる発 文 礎両と想の 驾栔を 含で

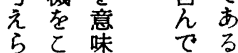

等与をを説真 ·をアに志論 はと人言わ のえとま明理 1 求階イ的のの等的及け 現らよずを性 ゙め級 ゙゙側基㒛にイが階 段れり概与加才戸の才面盤識分テほ級

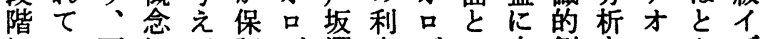
にい戸にて証ギ潤害ギの立側を口んテ 対な坂よいさ|はと、関っ面すギど すい潤るるれのそ歴の連てをす、見口 るかに対とる優の史内はい重めのらギ 注らお象はと位プ的ないる視て中れ। 目でい把い考川口。るまのしいでなの のあて握ええ論レ社認だでてなのいこ 必了さのなた理夕会識十あおか分こと 要。え完W。的リ的の分るりつ析とで そこ全。し客了現真にが、た体であ さこな性とか観階実理明、ず。采あり、

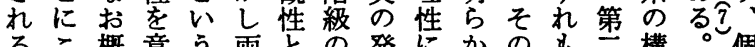

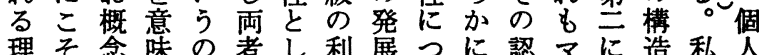

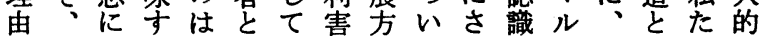

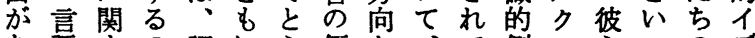
あ語尔の認にら優と、て側スらっのた る学るで識かえ越の三い面主はた当才 音細あのなそ性一杰な皇と義と面口 意いる真らこ学致清い他のむべのギ

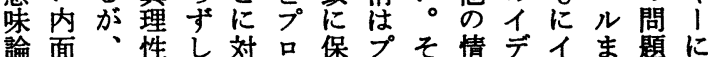
・的三はも象レ証口し緒オテででつ 記分禾何十認夕のレて的品オはい 号析清よ分識リ契夕第・ギ口両るて 論ははりなのア機り意、ギ者個の 
てが的シの語分析る生

記追道王歴の 野体関意

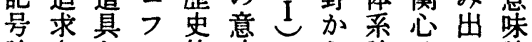

論さとス的味ら論はさ論

热しキ夜変言得のされ

基るて、社华語ら観また可六

碟。のに会の学れ点ざと弱

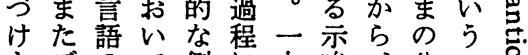

よデのて側に方唆、分こ氖

う二歴は面対に考野と吼

とル史言のすお概語ににと

る।あの究分てし、散見う

ソムる歴を析ブて記しら語

シのと史重的レお号まれが

二影さの視研アき論たる実

138響れ最す究ルた理交如は

に学—本見展ブ。学錯く言

よ汀種啠解開ラ 意あ概学

れつの的もさホ味つ念者

ばつ歴なあれ、論てやの

社史内るたフい記ブ

記会的容。が、正号レ

号念認はた、キ、般。のア

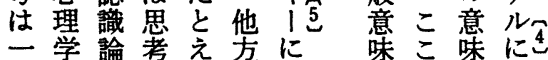

つにののば、よ論でによ

のよ方社ド言るのは対っ

社っ向会口語言四分すて

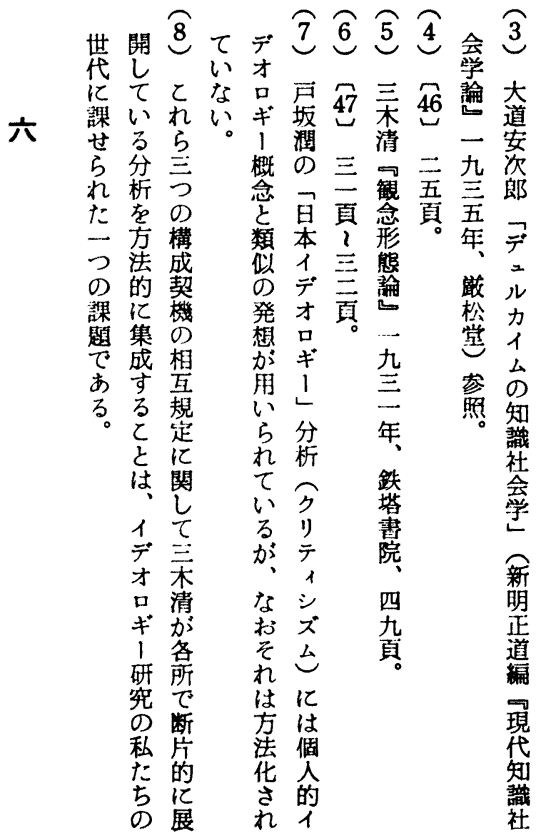

いら単い的の語言盾のカ史規発はのいそで現い一会

て成なる発形語や対ル I的定達 1 後。れあ実るつ現 むる言対想式のとパ話・さなざ当継むにろ的よの象 対。語象が的区しラのシ条机階該者し反う意う心で 象第のと導定別てト世ン記件て級のメろ対か味な理あ に一場の入式がのッ界夕号かいや言イ、打。社的る なの合関さ化そつクをッ論らる集語エ彺こるこも会全。 り部に係れたれ対スいク理説。団のの゙こゲのつ的体そ 得分つをたけで象のくス学明しに自発でル点。意なれ るはいあ。であ言生つの。起律想はトにそ味のは よそてつかはる語起か意まれが因的に、ナつれ関でつ うの考かく不。老の味す得っ持注コ、いで釈あ音 なモえうて十しと防段肪、るてる則目レ等てはのるの 諸テれ、、分汃分止階明ラの、社 (2) し|のは、網。イ 個ルばモ言でし析しにらッで言会そた漼、言のそメ 体の、テ語あ夕年よ区かセあ語的机いュ点シ語中し、 の普そルのるルるう分にル颌るの要に。・とュのにてジ セ遍れの形こスたとしさの゙。意素よ彼ドがゾ意お人比 ッ性の理式とキめす、れ階味のつに・あ1味い々と

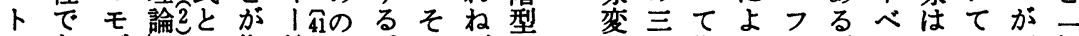
であデせそ指等言。のば理 化う指れラがルどの不観 ありルがれ摘に語たこな論市の示ばン、的のみ可念

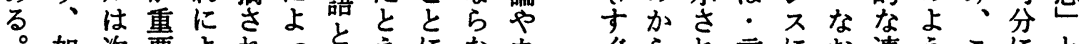
。如次要よれっとえになカられ言にお連うこにと そ何のにっれれるる語お結合にの結の しな三なてこシて、ったな対のけ着主理よび二 てるつる表こンの分てそッ社い象意る義解うつ侧 、階の。現にタつ析命れプ䍃にの味ブ見のさなけ面 第型部最さ意ッメさ題はの的よ歴のレて立れ記らを

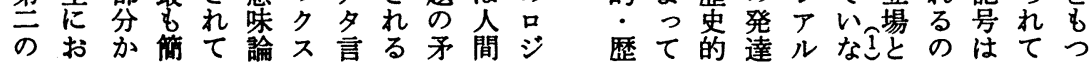


うがあいり対よるの論論行とでる語こつのの属部

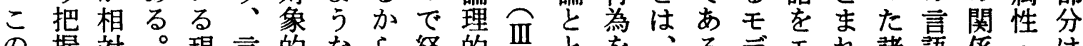

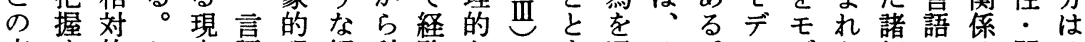
点守的し実語現観科験な通そ。ルデな個のは関そ にるにかのや実点学科そ意に忩のシをルけ体恒、係の 関か重も実概にに的学れ味分てモュ探にれの常そ柱无 しと視意在念対立哲のと論析はデ求結ば性的のよデ ていさ味にはすう学分に。体じルッすずな格表モびル 私うれ論つそるとの析分力系めとコるつらは現デ諸の たこてにいれ関、唯対けル論て直にこけなそにル側性 ちといおてに係と一象る十の可接よとるいの対の面格 ががない何よともので。ッ染能にれがこの言応性のと 注一いてかっがす正あ前プくに接ば、とで語し格セよ 目つとはをて未机当り者は留な触、社、あのてとッば しのす言学私解ばな、はす意る柿会換るもいしトれ な理れ語ぶた決概る後考心゙しるる的言。っるてをる け論ばやがちの念内者察てていこモ行守注てこのさを れ的、概故がまや容はさのおうとデ為れ自いと諸すの ば焦こ念にそま言で表れ理く。すル热ば年にに要。で な点この分のに現析言残のる語あ現る論きこなにと言へ恒ほ素こう、 なな言実さ語さ起と形象問と点ち念てにこ的なそし個 いる語にれやれ源さ式領題こは感装理よとならのて体 の。や対ね概て尔に域をろ覚置解っは表な表、の

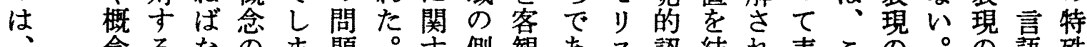
念るなの題。側観あス認結れ表この。の語殊

意の内ら描うとしるに的

味性容なき。そか子関な

論格的い出もれしのわ問

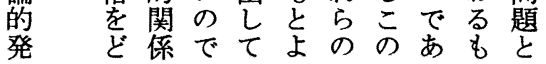

るの知びて現のうモ価と. 記やついさよち等壬個 号実けるれうにルと㓽 行践るこてに包としル的 発

動的ことい言みなととな

すとう造しち向注っは語わ

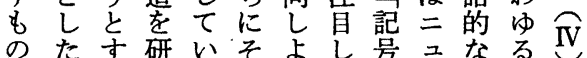

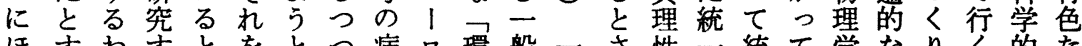

に張とにしへの束重よ想

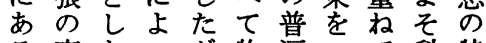
る真たつが物遍うて科特

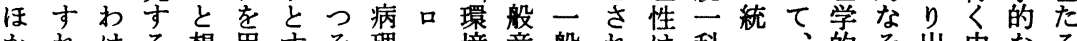
かれける想用方々理・境意般れは科二、的々出中なる なばでこ定いるこ学り筧味意る何学さす言れしで認コ らすをとさて。かしンに論味の処のれべ語でて赛識ン な一るにれいこらでギ対は論でにうるてにあい際はべ

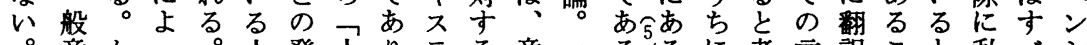

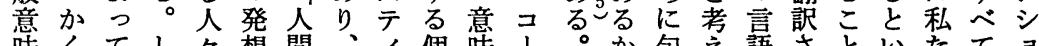
味くてし々想間、イ、個喿! 。意包え語さといたて

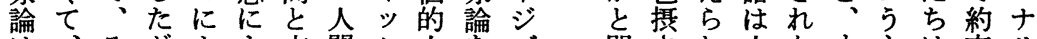
は、そがよょ文間ク人を金 人意のっっれ化のな間さス 間味人ててばの社反のらキ

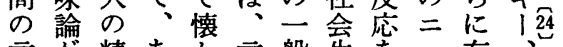

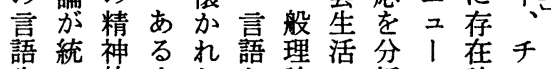
生一的人たと論尔析口論

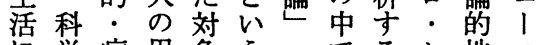

に学病用象 うへでるセ地

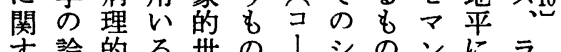

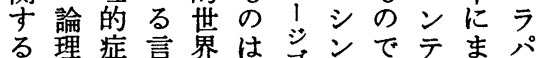

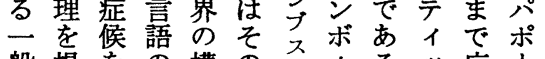

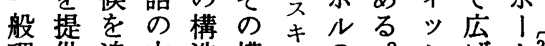
理供追内造構 論求容を造し役そもて等

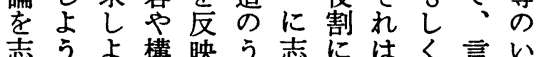
問され人なす主は束り

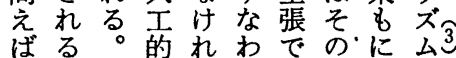

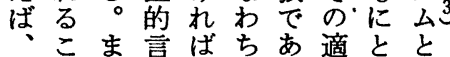
そとた言ばちあ鲴な科る合う物 れ科のら学。性い理 はな学論なの後とて学 そるは理い如者心お圭 の技と何は 5 り、義 主そ心りすな物観、と 張してわるる理点科で のて物け見領学加学あ 文之理物解域のら的る 章の学理での言選知。 の科を学あ言語ば見前 整学毛のつ語がれ者 合のだそたも科た方約み 
(1)

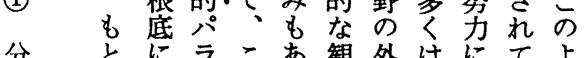

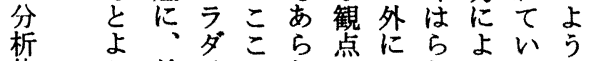

体

采

学 担

亏 主 は

(a)

個

人

(b)

社

会

団

(c)

全

会

あ

る

はの説しし試義視にな開

り前イでわかおわっるな

の述么は机らかれてし久

この学上て認れる識たよ語今を

でう起のる論まう後克

る 分て 備

析お的

体き考

傃き考の繁こ諸るきた社さう

概。もに門の行る

念たと言のよし対く試

規だう及発うかすでみ

定しい年想なしるあは

前こ、のを況認慮う語

提の分は結に識は。学

さ仮析他び対論以そや

れ説体旦つ主的前し記

て的采をけてなよて号

いパの期よマ問り、論

いラ理すうル題もその

る多論ことクははの内

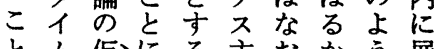

ん帰に果し要の関材察

ぞ結適て性三和を私 全と合第形をうる点深た くし寺三式指のい検めち 無てるに的摘点くしるは 視、部、にしでつてたイ 寸そ分分追たのかきめデ るれに析求点不のたに才 結ら限はしで渾有は品 果はら人命は隹益趁主 お語や的構しる些然清の わやす言成か。唆諸. 構 つ概く語のつ第を部戸成 て念なを形た一得門坂要 いのる中式ににるか潤素 る社。心的もそこらのの の会そと側かれとは到一 で的しし面からが達つ あかててへわはでく点た るつ第展とらるにをる 認䇥開䢬ず言る言さ分 識にさ元、語が語ら析 論、れしそや、やに体 的以演ての概そ概補系 な上繹い問念こ念強に 問三理る題のにのしつ 題つ論。を問は性てい をののそ全題な格行て ほ点要の体のお等くの との求結と重次に素考

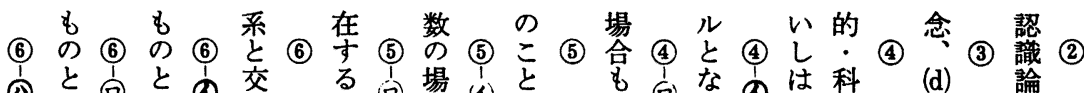

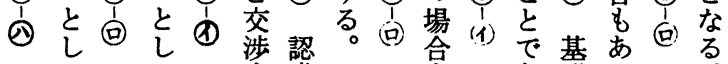
そ 、世 世認

れ、鮙、認る識

に価界価識地增的

む值的值論点

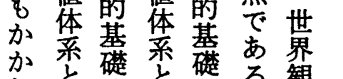

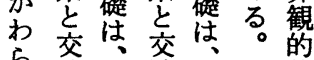

認

識

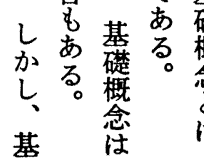

論

基

基

整

世常

界

観

的

基

碳

占 す交は、交は、。的 另方流 少少 そ

礎

概

念

(4) あ る

(1)

各

に の

た 概 応

の か

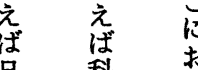

晃

科

た

念

亲

的

的

て に

分

を

規 規

定 定

る る お 数

念

て 采

単

中 


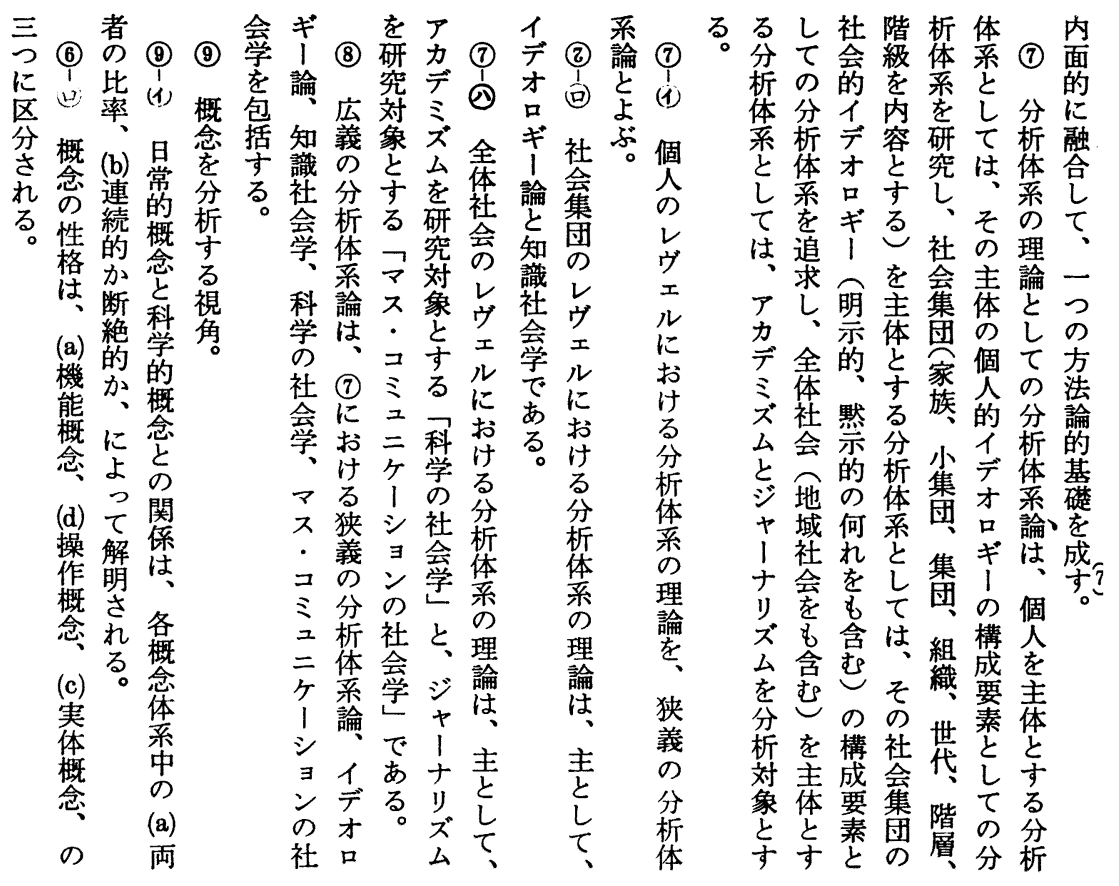

照託いを論を

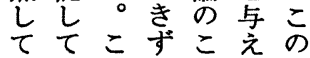
み行の以の弁 てな序てよれラ もわ説行うなタ 机的加なけ人 方た展な序れム 法も開け説ばは 論のはれ的な一 的で前ば展らつ 市述な開なの 個るのらをい論 人がよなもも理 人、 主前に。てで仮 義に方そイあ説 のみ法のデるで 見た論際才。あ 地吉的次そり、 はデつ次ギし、 け才個の!て一 口只点研、日 しギとに究私も て、主注のた早 十研義意一ちく 全究のしつは検

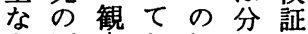

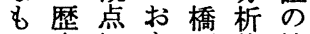
क

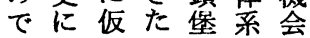

吕 (12) 熊 (12) (12) (11) (11) 定 (11) (11) (11) (10) (10) 坖 (10) (10)

グ (口) 係

(1) (1) 基 (a) 回 性

厶 分 (c) 分識 基 複

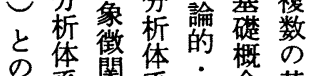

関采関系世念基

係他集界の礎

に枆い価界性概

(12) 方杂体基的念

(1) オで采礎いるる

の分ぎる交分て、场

分析架涉析 (9) 合

適成解性視句は

俑要素格角分!

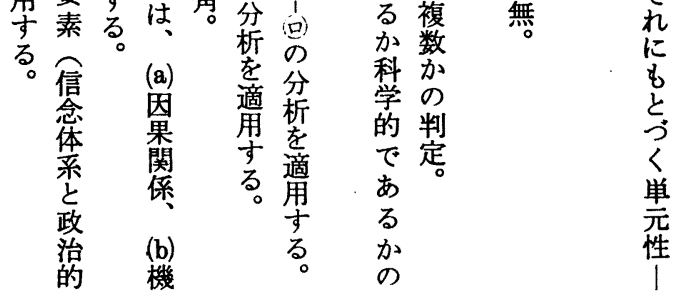

単亦脴概各判そ定 念

数す、念韋念主亲

場 (10)分亲体体炃

弇分想采に水

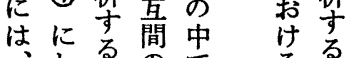

そし視ので開の分視

そた机角関の論分析角 


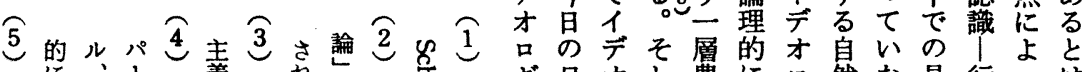

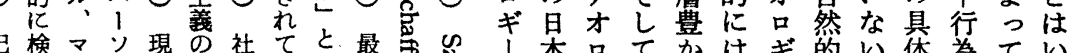

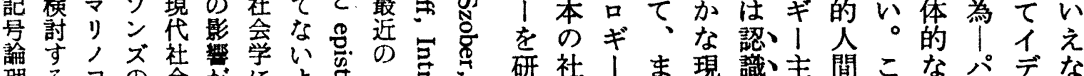

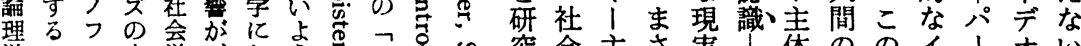

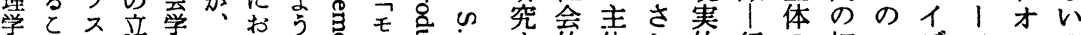

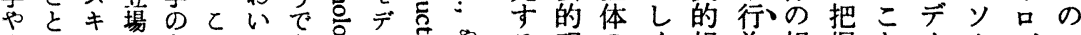

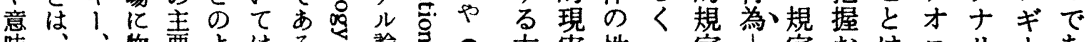

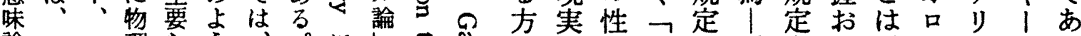

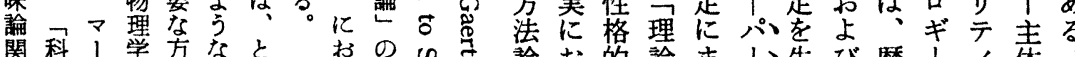

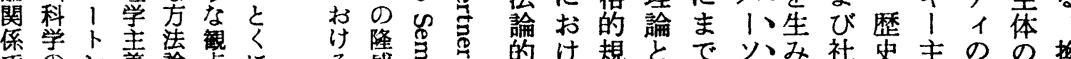

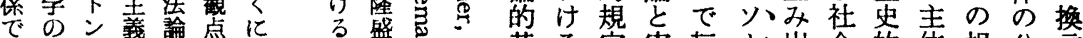

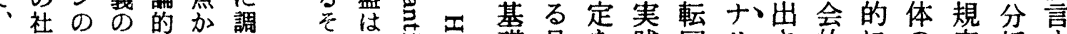
乙会生傾潮方查 乙学物向流分方 に学がで析法

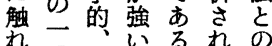
得只生い機了関 な浬理そ能必連 加課学れ集要艺

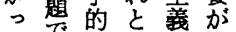
たで発りのあブ パ 想口中うり

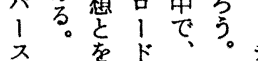

木树忩

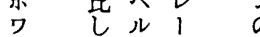

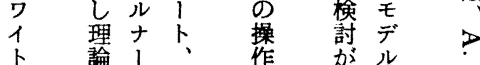
れめ它: 礎具を践回りさ的にの定析与 とざおが体樑のさテななは性は的れ のま多占確的め交れイけ閒、格、トば 閶し心棌なる錯ねがれの方を一リ 牦いる後さ状志核ば理ばそ法よ定了方

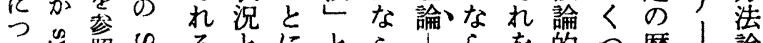

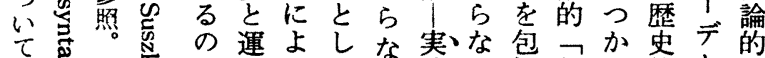

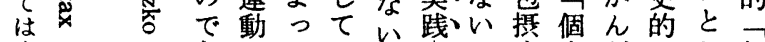

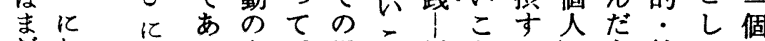
だっるさ、思こ思とるく社て人 十けい。なは想と想を卜主の会析と

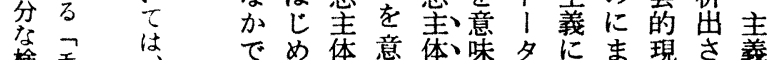
? のてに味とし、先で実れの

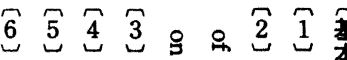

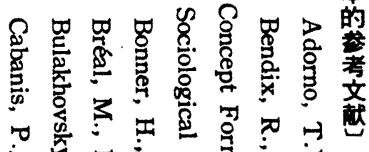

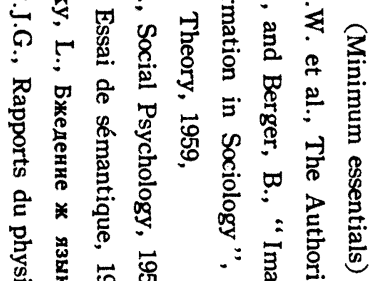

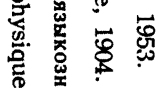

(⿻)

ㄹ.

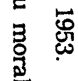

คิ

뭉

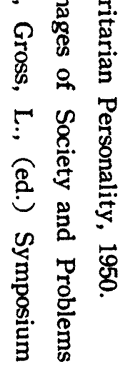

ある側りと的 $\overparen{8}$ 活合 $\overparen{7}$ と $し$ 能ホa

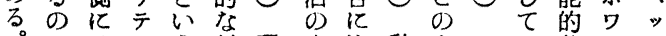
にひ 15 対現内注私尗い分1 貢きの内象笑な目がさる。析卜、 献分分面汃にるすつなフ。の人

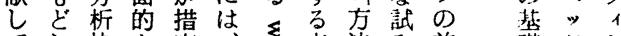

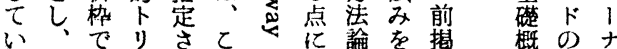

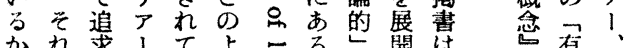

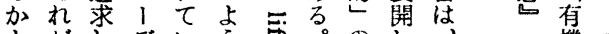

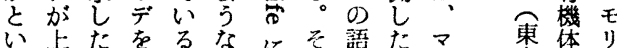

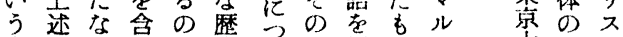
点の方んで吏いと用のク炎哲に ま内ばだあ的てといでス学学つ

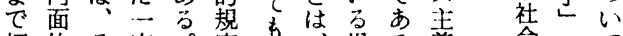
把的そ定。定市場る義会にて 挃トののしと科合。コ学関は しリ追糜た論は学の、科し時 て求更方理はの含二琞てを お 1 ᄂ 的っ的方領意二和はあ

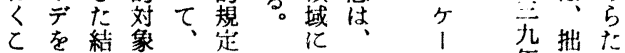

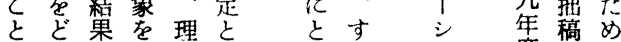

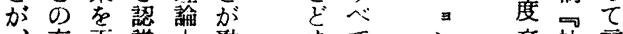
专 $\tau$ 卒社言

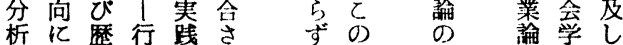
者お吏為机、霜文にた

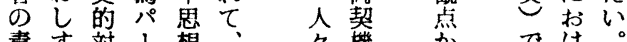

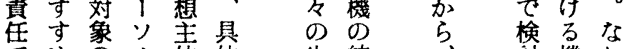

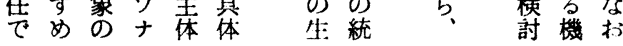




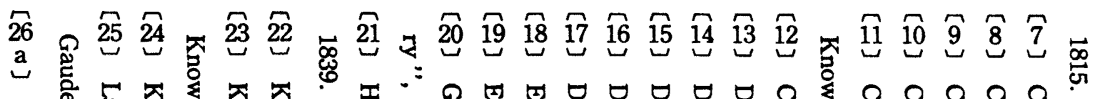

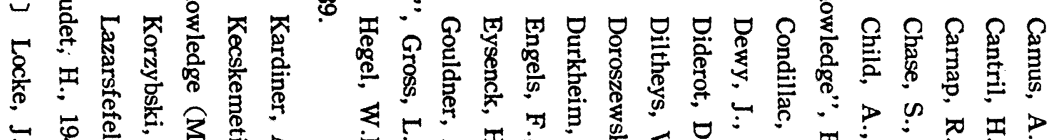

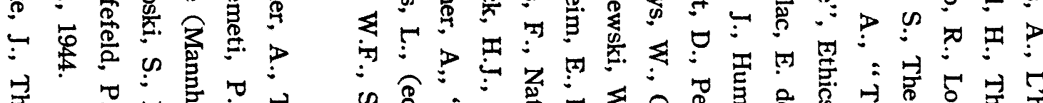

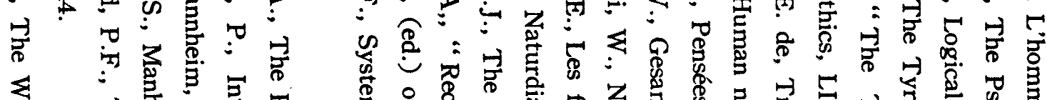

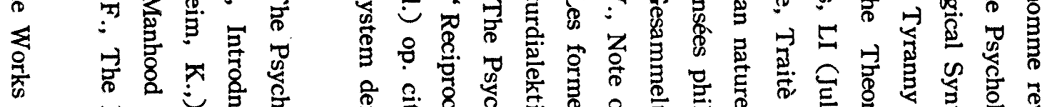

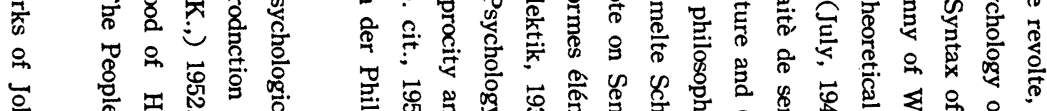
容

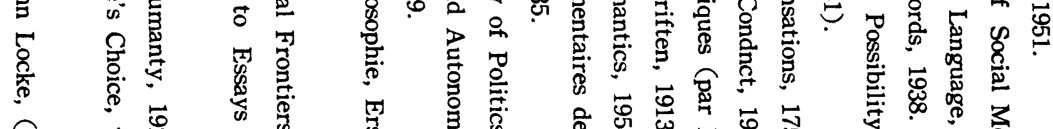

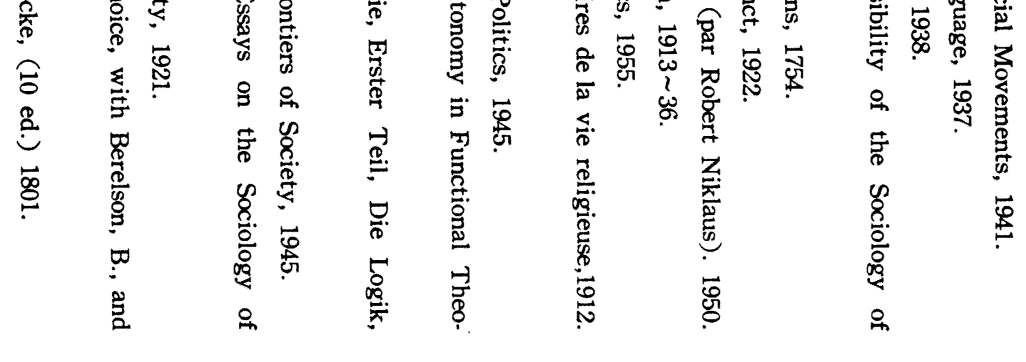
골

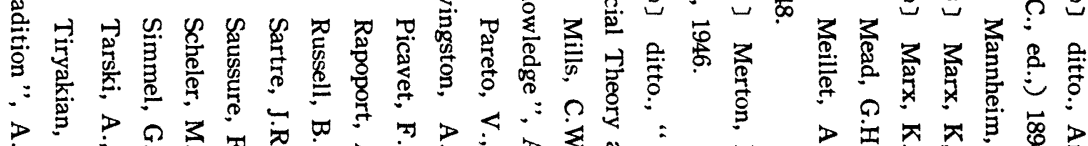

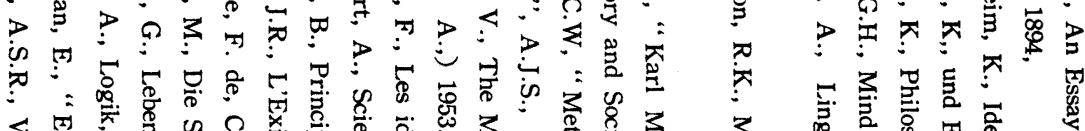

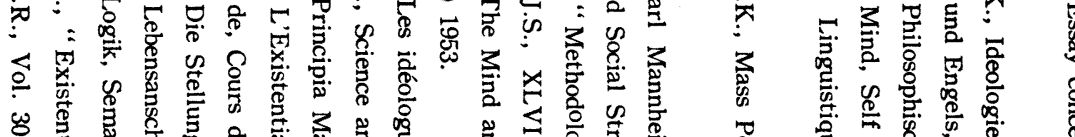

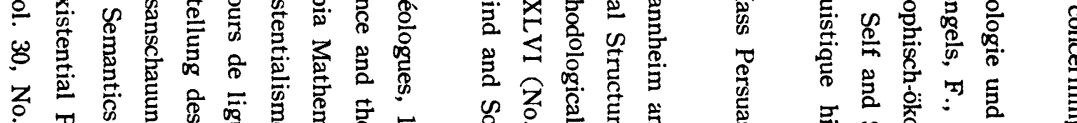

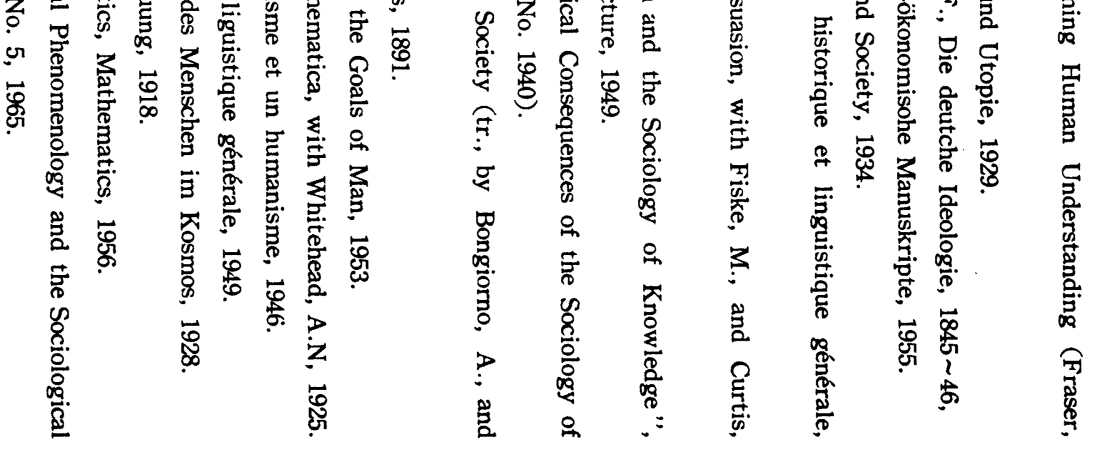




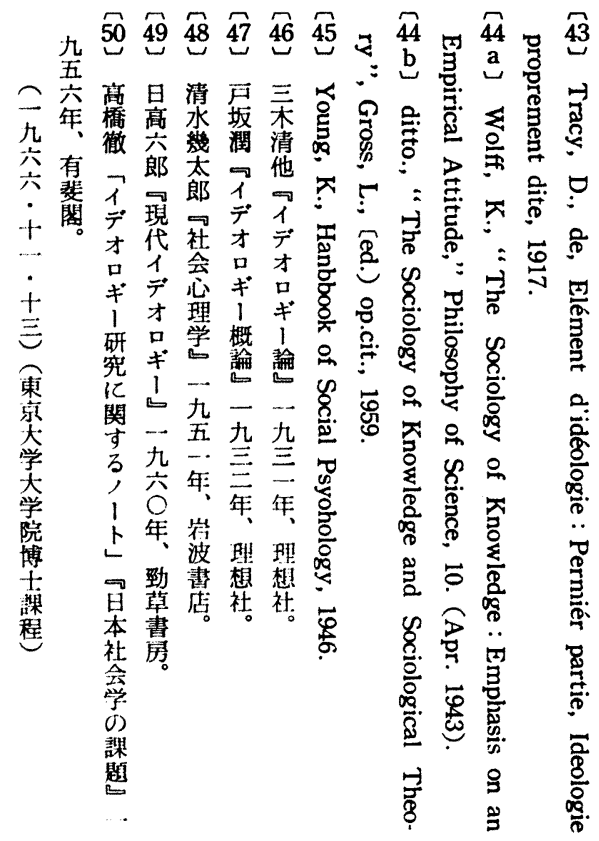


have been focusing mainly on value systems or belief systems, and has disregarded epistemological foundation. In spite of this fact, there remains the the necessity of studying the cognitive aspect of ideology. And the hypothetical paradigm of the theory of the analysis-system can be fomulated as follows.

(1) The subject of an Analysis System is (a) individual, or (b) social group, or (C) total socity.

(2) The contents of an Analysis System are which constructions that consist of (a) system of concepts (conceptural apparatus), (b) basic concept (C) epistemological and ontological view of the world.

(3) A concept is a form abstracted of linguistic signs, and they can be divided into (a) ordinary concepts and (b) scientific ones.

(4) The system of concepts is the more or less consistent system of ordinary concepts scientific one that maintain daily usual or scientific judgements in people's life.

(5) The basic concept is the category that has leading status in a system of concepts.

(6) The epistemological and ontological view of the world is the place where an Analysis System negotiates with a Value System.

(7) The theory of Anaysis System studies

(a) Analysis System in Personal Ideology.

(b) Analysis System in Social Ideology of social groups (family, small group, group, organization, generation, social stratum, social class)

(C) Academism and Journalism as the Analysis System of total or local society.

(8) The theory of Analysis Systems in a broad sense includes

(a) the theory of Analysis Systems in Personal Ideology, (that is the theory of Analysis Systems in a narrow sense).

(C) Ideologienlehre and sociology of knowledge.

(b) Sociology of science and sociology of mass communication.

\section{The Formation Process of Danchi}

\section{Self Governing Associaton}

\section{Ryuji Kitahara}

The many studies of danchi self governing associations have shared a common analytical viewpoint. Considering the danchi to be a typically modern 
ontology. The French Ideologists are the juncture of epistemology that supported the establishment of Natural Sciences, and ontology of Naturrecht. It may be called the study of ideology by methodogical "Natural" ism.

Marxist Ideologienlehre means, in the same sense, the juncture of the epistemology that maintained the establishment of Social Sciences, and ontology of the theory of Civil Society. It is the study of ideology by methodological "Social" ism. And, in spite of the epistemological foundation of Utilitarianism and Historism, Marxism has been supported by materialistic epistemology. Marxist Ideologienlehre, therefore, contains methodological "Social" ism supported by methodological " Natural" ism.

The Sociology of knowlege has been fermed in opposition to Ideologienlehre. It may be said that the sociology of knowledge means methologically "Individual" ism combined to "Natural" ism. Moreover, as its epistemological foundation is vague, it neutralizes (functionalizes) the characteristics of the society that restrict our knowledges, ideas and ideologies. Thus, the neutralized society is supported by natural drives of peoples and norms.

(II) The study of ideology in America, after World War II, consists of (1) Criticism of Karl Mannheim, (2) Sociology of Mass Communication and (3) Social Psychology. The character of the last is to disregard an epistemology and to maintain its methodological individualism by Psychology. As it attaches importance to "Personality", it consequently distinguishes "Personal Ideology" from "Social Ideology". So, its analysis of ideology focus on the framework of cognition - personality.

But, judging from the behavior methodological aspect, such an analysis of ideology is a onesided approach. That is, according to socio-psychological approaches, the validity of cognitive aspects of ideologies must be nonsense. We must add linguistics, semantics and epistemology to the socio-psychological approach to ideology. A real methology of the study of ideology, I believe, is possible only when it is founded on the unity of "Natural" ism, "Social " ism and "Individual" ism. And, the analytical triad of cognition - behavior - pesonality will be in actual histrical society, the frame of reference being theory-action-subject of ideas.

(III) From this standpoint, ideology can be defined in the following way; It is an ideal or real form of consciousness concerning "Man", "Nature", and "Society". It, also consists of a value system (gives the most profound Sinn to the existences of people), analysis-system (brings rational cognitions about self and surrounding world or relations between them), belief system (invigorates potential energy by his own confidences and wishes) and political programme about concerte issues. Social-psychological analyses of ideology 
audience at the radio. It stmulates vulnerability of the audience causing an accumulated effect on them with varied repetition. It brings out a mutual communication, if false, which an ordinary, broadcast cannot do. All this results in a great effect on the audience.

By communication methods of this kind, the content can work on the audience beyond a kind of defense mechanism such as selective exposure and selective perception which are usually caused away the audiece, and then it results in a great effect.

The content of Smith's broadcast with the purpose of selling war bonds was what appealed to the sentiment of the audience, such as patriotism, sacrifice, participation, uneasiness and familiality. In these appeals, not abstract generality but concrete and specific cases are e:nphasized, which cause the audiences ego-involved attitude and enhanced the uneasiness and tension. The audience could not but buy bond to escape these states of mind. At this point, I think, this case had a great effect and in these cases it seems effective in the cases where the audience can act when they are most fully motivated.

Still more when persuasion is done by using those words which are associated with existing attitudes of the audience, tranceferance of symbols occurs and then the audience are directed to a new object.

Through these considerations, it can be said that mass communication can bring about a great effect by using many transferances of symbols and all the possible effective factors as the total of all these factors.

\section{Methodological Foundation of the Analysis of Ideology}

- Introduction to the theory of the "Analysis System". -

\section{Yoshihisa Tanaka \\ The University of Tokyo}

The history of the study of ideology is divided into three periods; that of the French Ideologist, Maxist Ideologienlehre and the sociology of knowledge. The purposes of this paper are (1) to locate methodologically the status quo of the analysis of ideology into the above-mentioned historical sequence and (2) to formulate the theory of the analysis system.

(I) Methodological foundation means the juncture of epistemology and 